\title{
The roles of surface heat flux and ocean heat transport convergence in determining Atlantic Ocean temperature variability
}

\author{
Jeremy P. Grist • Simon A. Josey • Robert Marsh • Simon A. Good • \\ Andrew. C. Coward - Beverly A. de Cuevas - Steven G. Alderson - Adrian L. New • \\ Gurvan Madec
}

Received: 13 November 2009/Accepted: 15 April 2010 /Published online: 7 May 2010

(C) The Author(s) 2010. This article is published with open access at Springerlink.com

\begin{abstract}
The temperature variability of the Atlantic Ocean is investigated using an eddy-permitting $\left(1 / 4^{\circ}\right)$ global ocean model (ORCA-025) forced with historical surface meteorological fields from 1958 to 2001. The simulation of volume-averaged temperature and the vertical structure of the zonally averaged temperature trends are compared with those from observations. In regions with a high number of observations, in particular above a depth of $500 \mathrm{~m}$ and between $22^{\circ} \mathrm{N}$ and $65^{\circ} \mathrm{N}$, the model simulation and the dataset are in good agreement. The relative contribution of variability in ocean heat transport (OHT) convergence and net surface heat flux to changes in ocean heat content is
\end{abstract}

Responsible Editor: John Wilkin

J. P. Grist $(\bowtie) \cdot$ S. A. Josey - A. C. Coward - B. A. de Cuevas •

S. G. Alderson - A. L. New

National Oceanography Centre, Southampton,

European Way,

Southampton, Hampshire SO14 3ZH, UK

e-mail: jeremy.grist@noc.soton.ac.uk

R. Marsh

School of Ocean and Earth Science, University of Southampton,

European Way,

Southampton, Hampshire SO14 3ZH, UK

S. A. Good

Met Office Hadley Centre,

FitzRoy Road,

Exeter, Devon EX1 3PB, UK

G. Madec

Laboratoire d'Océanographie et du Climat: Expérimentation et Approches Numérique, Paris,

France and National Oceanography Centre, Southampton, European Way,

Southampton, Hampshire SO14 3ZH, UK investigated with a focus on three regions: the subpolar and subtropical gyres and the tropics. The surface heat flux plays a relatively minor role in year-to-year changes in the subpolar and subtropical regions, but in the tropical North Atlantic, its role is of similar significance to the ocean heat transport convergence. The strongest signal during the study period is a cooling of the subpolar gyre between 1970 and 1990, which subsequently reversed as the midlatitude OHT convergence transitioned from an anomalously weak to an anomalously strong state. We also explore whether model OHT anomalies can be linked to surface flux anomalies through a Hovmöller analysis of the Atlantic sector. At low latitudes, increased ocean heat gain coincides with anomalously strong northward transport, whereas at mid-high latitudes, reduced ocean heat loss is associated with anomalously weak heat transport.

Keywords Atlantic Ocean - Ocean heat transport . Air-sea fluxes . Ocean heat content variability . Ocean model

\section{Introduction}

Recent decades have witnessed a marked warming of the Atlantic Ocean. The mean basin-wide temperature increase has been estimated as $0.30^{\circ} \mathrm{C}$ above a depth of $700 \mathrm{~m}$ between 1969 and 2008, nearly twice as much as that over the Global Ocean for the same period (Levitus et al. 2009). Within this substantial increase, however, there has been considerable spatial inhomogeneity. Notably, the temperature of the subpolar gyre region dropped by some $0.1{ }^{\circ} \mathrm{C}$ between 1970 and 1990. Understanding the mechanisms behind these changes is crucial for improving the seasonal 
to decadal scale climate prediction of the surrounding continents. For example, research and operational forecasts of European winters, the West African rainy season and North American land falling tropical cyclones rely on Atlantic Sea surface temperatures (SSTs) as predictors (Philippon and Fontaine 2000; Klotzbach 2007; Scaife and Knight 2008; Tompkins and Feudale 2010). The principal processes responsible for changes in Atlantic Ocean temperature or heat content are the different components of both (a) the air-sea heat flux and (b) the convergence or divergence of heat via horizontal ocean heat transport (OHT), which is often associated with changes in the wind forcing (Biastoch et al. 2008a). As such, an important step to understanding recent Atlantic temperature changes is to quantify the contributions of the two different components and their interactions.

A number of studies into the mechanisms associated with Atlantic temperature changes have been undertaken using observation-based datasets. By combining hydrography and altimetry, Häkkinen and Rhines (2004) showed that warming of the subpolar gyre in the 1990s was accompanied by an increase in sea surface height (SSH) and a reduction in the strength of the gyre circulation. More recent results (Häkkinen and Rhines 2009) indicate that the subpolar gyre circulation continued to decline through 2005, which, together with changing surface currents, has implications for the ocean temperature at higher latitudes. Meanwhile, comparisons of temperature changes at constant density with those at constant depth suggest that between 1950 and 2000, changes in the sub-tropical gyre were associated with the deepening of density surfaces, caused by Ekman-induced heave, whereas in the subpolar gyre, changes were due to density-compensated water mass changes (typically due to air-sea fluxes; Leadbetter et al. 2007; Lozier et al. 2008). However, a recent combined analysis of hydrographic data and Argo floats between 1990 and 2006 suggests that the density-compensated changes in the subpolar gyre ceased in 1996 (Thierry et al. 2008).

A number of investigations have taken place using ocean-only model hindcasts forced with atmospheric surface conditions, typically from atmospheric reanalysis products (e.g. Böning et al. 2006; Biastoch et al. 2008a; Marsh et al. 2008, 2009). From such a study, using a model run spanning 1985-2003, Marsh et al. (2008) found that the mid-latitude warming that took place after the mid-1990s could be associated with the anomalous convergence of meridional ocean heat transport in the region. In this paper, we use a hindcast from a $1 / 4^{\circ}$ eddy-permitting ocean model, forced with observation-based surface fields, to diagnose the mechanisms of temperature change within the North Atlantic over the longer period from 1958 to 2001. This approach is seen as complimentary to observationbased hydrographic analyses. However, unlike observational and model assimilation studies, it is not affected by temporal changes in the distribution and quality of sub-surface observations. Furthermore, being only constrained by the model governing equations, with the exception of some minor terms, we are fully able to close and account for changes in the regional heat budgets. Our hindcast also benefits from being spun-up for 44 years and being of longer duration than those in earlier works (e.g. Marsh et al. 2008). We thus anticipate results that are not adversely affected by temperature drift and which can also be put in the context of the longer-term changes that have occurred in the Atlantic since 1958.

The structure of this paper will be as follows. The details of the model and the surface forcing used in the hindcast along with the observational dataset will be described in Section 2. The results in Section 3 are divided into four parts: (a) model-observation comparisons, (b) the characteristics of meridional ocean heat transport in the model, (c) an evaluation of the terms contributing to the temporal evolution of ocean heat content, and (d) an analysis of the basin-wide evolution of ocean heat transport and surface net heat flux and the relationship between the two components. This is followed by the summary and conclusions in Section 4.

\section{Ocean model and observational dataset}

We make use of the ORCA025-N112 eddy-permitting 1958-2001 global ocean/sea-ice simulation implemented and performed by the DRAKKAR Group (2007) as part of a wider numerical simulation database. The model configuration is based on the NEMO (Nucleus for European Models of the Ocean) code (Madec 2008) which includes the ocean circulation model OPA9 (Madec et al. 1998) coupled with the Louvain-la-Neuve Ice Model version 2 (LIM2) sea-ice model (Timmerman et al. 2005). The configuration has a $1 / 4^{\circ}$ horizontal resolution $(1,442 \times$ 1,021 grid points) at global scale decreasing poleward (isotropic Mercator grid in the Southern hemisphere, quasiisotropic bipolar grid in the northern hemisphere). The effective resolution is approximately $27.75 \mathrm{~km}$ at the equator, but increases with latitude to be, for example, $\sim 13.8 \mathrm{~km}$ at $60^{\circ} \mathrm{S}$ or $60^{\circ} \mathrm{N}$. The model has 64 vertical levels with a grid spacing increasing from $6 \mathrm{~m}$ near the surface to $250 \mathrm{~m}$ at $6,000 \mathrm{~m}$. Bottom topography is represented as partial steps.

The ORCA025 model is driven over the period 19582001 by the DFS3 surface forcing function developed by the DRAKKAR collaboration. As detailed in Brodeau et al. (2010), DFS3 combines elements from two sources: the CORE forcing dataset (Large and Yeager 2004) from which precipitation, downward shortwave and longwave radiation 
are extracted and the ERA40 reanalysis (for the period 1958-2001) which provides $10-\mathrm{m}$ wind, $2-\mathrm{m}$ air humidity and $2-\mathrm{m}$ air temperature to compute turbulent air/sea and air/sea-ice fluxes during model integration using the bulk formulae proposed by Large and Yeager (2004). The frequency of DFS3 is monthly for precipitation, daily for radiation and six-hourly for turbulent variables. Climatological monthly runoffs (Dai and Trenberth 2002) are applied along the land mask. Initial conditions for temperature and salinity are derived from a monthly climatology that combines the Levitus et al. (1998) World Ocean climatology with the PHC2.1 database (Steele et al. 2001) in high latitudes and the Medatlas climatology (Jourdan et al. 1998) in the Mediterranean Sea. Following a first integration from 1958-2001, the end-state of 2001 was then used for the start of a second integration using the same forcing set. The first pass therefore served as a model spinup. The analysis of the second integration, which hereafter is referred to as N112, is what is considered here. To avoid unacceptable drifts in salinity, the sea surface salinity is restored towards the monthly mean climatological values. This relaxation timescale is 180 days for the open ocean and 12 days under sea-ice. The model outputs are archived as successive 5-day means throughout the whole integration. More details about the model configuration maybe found in Barnier et al. (2006) and Penduff et al. (2007, 2010).

In addition to the model, we use the UK Met Office EN3v1c observational dataset (http://www.metoffice.gov. $\mathrm{uk} / \mathrm{hadobs} / \mathrm{en} 3)$. EN3v1c is an update of EN2 described in Ingleby and Huddleston (2007) consisting of qualitycontrolled temperature and salinity profiles from 1950 to 2006. The original sources of the profiles include the World Ocean Database (2005), the Global Temperature-Salinity Profile Programme (from 1990) and profiling float data from the Argo Global Data Assembly Center (from 1999). The product is an objectively analysed version of the data with $1.25^{\circ}$ resolution and 40 vertical levels over the Global Ocean.

\section{Results}

\subsection{Model—observation comparison}

In this subsection, we compare the spatial and temporal variations of the Atlantic temperature in the model with that from the EN3v1c observation dataset in three different ways. We examine spatial maps of the temperature difference between the second half of the integration and the first half, the latitude and depth dependence of the zonally averaged temperature trends and the temporal evolution of the volume-averaged temperature for different regions.

The difference in the temperature of the top $500 \mathrm{~m}$ between 1982 and 2001 and the previous 20 years (1962-
1981) as determined from the EN3v1c observations is shown in Fig. 1a. The corresponding field from N112 is shown in Fig. 1b. There are strong similarities between the fields, especially in the North Atlantic. Both representations indicate that the latter period was significantly warmer in the Nordic Seas, cooler in the Labrador Sea and northern half of the subpolar gyre and warmer to the south in the range $30-45^{\circ} \mathrm{N}$. As for the rest of the Atlantic basin to the south of $30^{\circ} \mathrm{N}$, the latter period was predominantly warmer. However, in addition to these areas of agreement, there are also some noticeable differences. First, the changes tend to be stronger in the model integration. Second, there are two distinctive areas of cooling, a band that stretches across the basin at $30^{\circ} \mathrm{N}$ and an area in the East Atlantic between $10^{\circ} \mathrm{S}$ and $20^{\circ} \mathrm{S}$ that are evident in the model integration but not in the observations. Furthermore, in the observations, there is some cooling in the tropical north Atlantic and at $40^{\circ} \mathrm{S}$ that is not seen in the model integration. When considering these changes in Equatorial and South Atlantic regions, it should be pointed out that agreement may be impaired by the modeldependent representation of Agulhas leakage. Biastoch et al. (2008b) have shown that introducing a $1 / 10^{\circ}$ nest into the Agulhas region significantly improves the simulation of the heat transport from the Indian Ocean into the Atlantic by reducing it compared to that in the coarser $1 / 2^{\circ}$ version of ORCA. In addition to this, the model observation differences need to be considered in the context of the low number of historical subsurface observations at these latitudes of the South Atlantic. With this in mind, we focus most of our subsequent analysis on the North Atlantic.

The mean temperature change, for 1982-2001 relative to 1962-1981, in the layer between $500 \mathrm{~m}$ and the ocean bottom, is dominated by strong cooling in the Labrador Sea — subpolar gyre region in both the observations and the model integrations (Fig. 1c, d). As in the upper ocean layer, the signal is somewhat stronger in the model integration. This stronger cooling at depth may reflect the deep surface-forced mixing in the model. This is illustrated in Fig. 2 which shows the mean March mixed layer depth for N112. A point of reference is the observational work of de Boyer Montégut et al. (2004) who, based on an analysis of profile data, conclude that $840 \mathrm{~m}$ is a reasonable estimate for the maximum depth of mixing in the Labrador Sea. By normalising the mixed layer depth by the depth of the ocean in Fig. 2b, it is evident that in parts of the Labrador Sea, the N112 mixing reaches the bottom of the ocean. With regard to the rest of the Atlantic, although the EN3v1c dataset shows some warming in the subtropical region of the North Atlantic, a marked feature is the lack of any large or coherent changes over much of the remainder of the basin. This is in contrast to the large region in the western South Atlantic that experiences a warming of about $0.1^{\circ} \mathrm{C}$ in the 
Fig. 1 Difference in the depth averaged temperature $\left({ }^{\circ} \mathrm{C}\right)$ between 1982-2001 and 19621981 for the Atlantic basin for 0-500 $\mathrm{m}(\mathbf{a}, \mathbf{b})$ and from $500 \mathrm{~m}$ to the bottom of ocean $(\mathbf{c}, \mathbf{d})$. a, c Are calculated from the EN3v1c observational dataset, whilst $\mathbf{b}$ and $\mathbf{d}$ are from the model hindcast N112. Note that the model data have been regridded to appear on the same grid as the observations a)

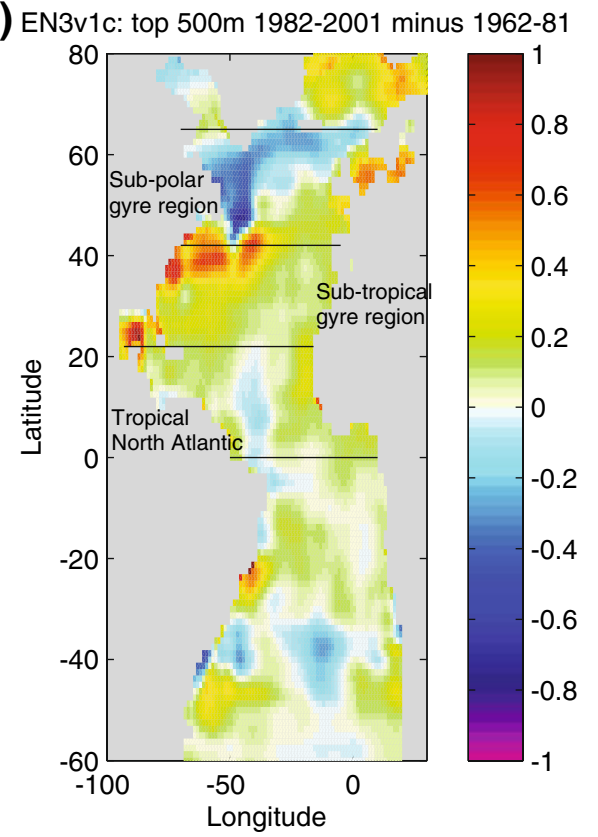

C) EN3v1c: 500m-bottom 1982-2001 minus 1962-81

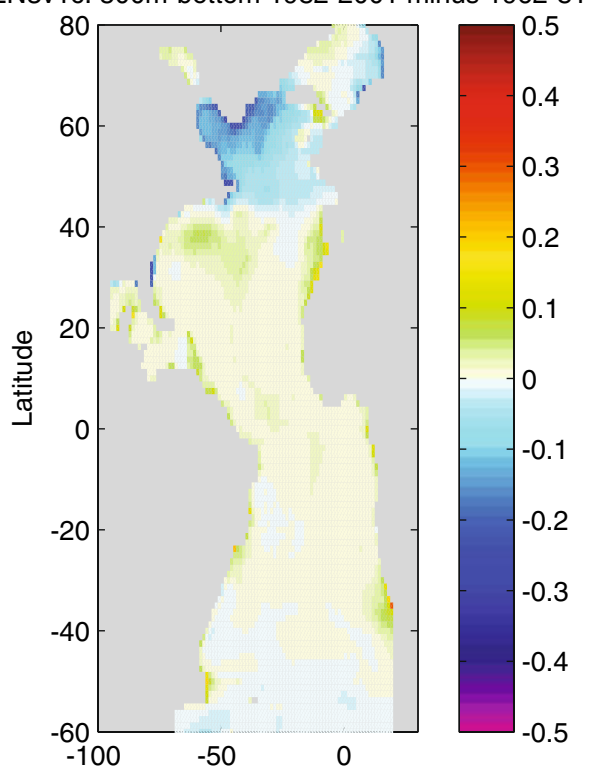

b) N112: top 500m 1982-2001 minus 1962-1981

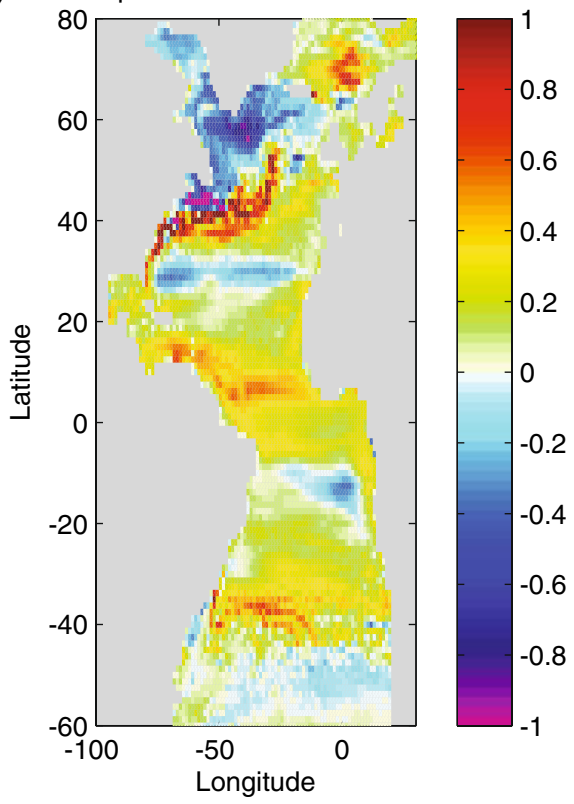

d) N112: 500m-botttom 82-01 minus 62-81

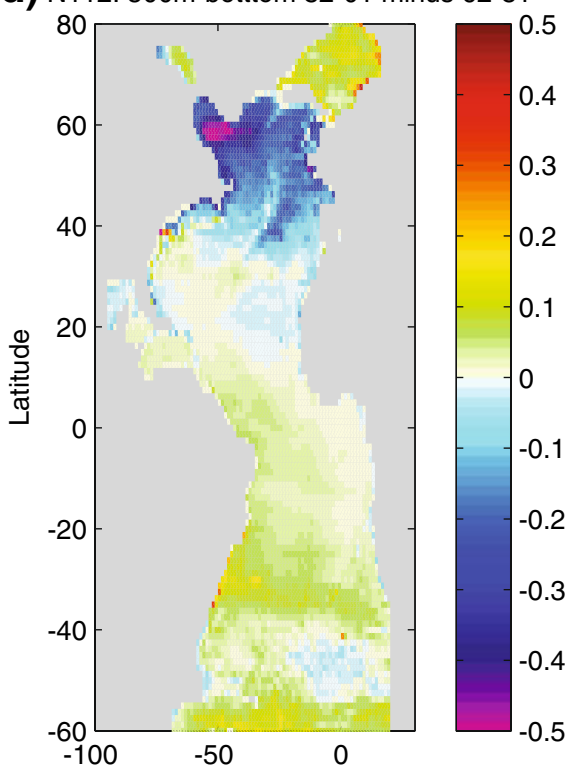

model run. The lack of a signal in EN3v1c may reflect the data-sparse nature of the observations at these depths south of the tropics.

Considering the sea surface alone, reasonable agreement of SSTs between the model hindcast and observations is to be expected as it is forced with surface air temperature from an atmospheric reanalysis product that has been constrained by observed SST fields, as discussed in Marsh et al. (2008). Of greater interest is the model's ability to capture how the vertical temperature structure changes in time. Consequently, we show the Atlantic basin zonally averaged temperature trend as a function of depth for 1960-2001 from N112 and EN3v1c in Fig. 3a, b, respectively. This model observation comparison should be considered in the context of Fig. 3c, d which shows the annual average (1958-2001) of the number of observations available in the Atlantic Ocean for the objective analysis. The numbers in panel $\mathrm{c}$ indicate the zonal averages of the number of observations for every $1.25^{\circ} \mathrm{x}$ $1.25^{\circ}$ grid cell, whereas panel d shows the zonal averages of the number of observations for every $10-\mathrm{m}$ depth of each grid cell. The region of greatest observation density is in the top $200 \mathrm{~m}$ between $30^{\circ} \mathrm{N}$ and $60^{\circ} \mathrm{N}$. The observation density falls off rapidly with horizontal and vertical distance from this point. South of the equator and below $500 \mathrm{~m}$, there are large regions where the mean number of observations is $<1-2$ each year for every 10 -m depth of each 
a) N112 Mean Mar MLD (m)

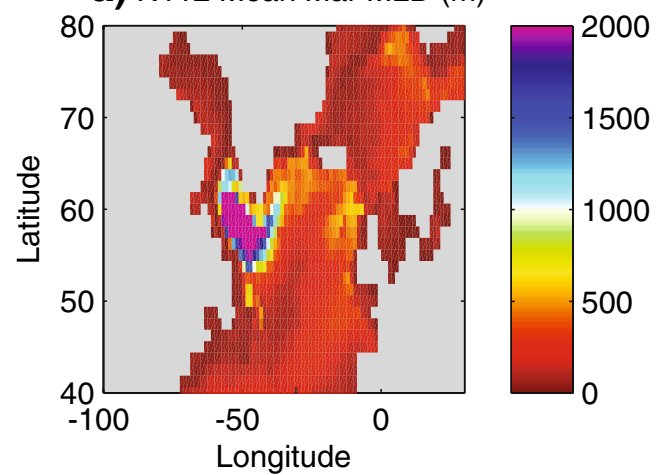

b) N112 Mar MLD as fraction of depth

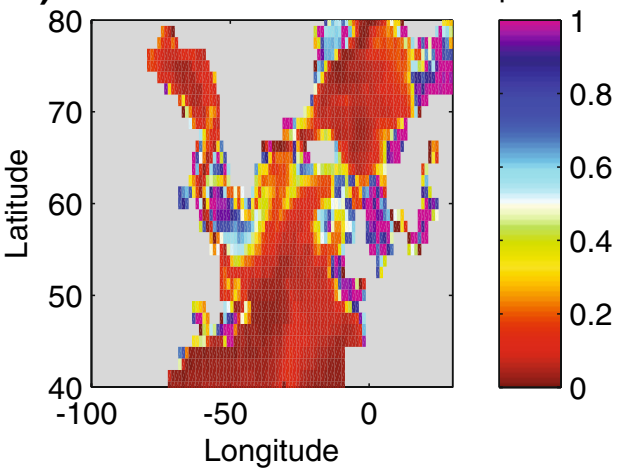

Fig. 2 a Mean March mixed layer depth (m) in hindcast N112 using a criteria of $|\Delta T|=0.2^{\circ} \mathrm{C}$. b The same as a, but with mixed layer depth normalised by the local ocean depth $1.25^{\circ}$ grid cell. Against this background, we note that there is a broad level of agreement between the model- and observation-based trends over this period, with some differences arising in the South Atlantic. The model trends tend to have greater definition and magnitude, and this is to be partly expected as the model has higher spatial resolution. One of the strongest features in the hindcast is the cooling of up to $0.25^{\circ} \mathrm{C}$ per decade in the subpolar region. Although the cooling is only evident between $50^{\circ} \mathrm{N}$ and $60^{\circ} \mathrm{N}$ at the surface, its latitudinal range increases with depth, and at $1,500 \mathrm{~m}$, it spans from $35^{\circ} \mathrm{N}$ to $65^{\circ} \mathrm{N}$. In the EN3v1c in Fig. 3b, a broadly similar feature is seen, although its southern limit is just north of $40^{\circ} \mathrm{N}$ and its maximum trend is only $0.1^{\circ} \mathrm{C}$ per decade. As discussed in Curry et al. (1998), the decline in subpolar temperature, in particular the cooling of the Labrador Sea Water near $1,500 \mathrm{~m}$, is also a feature of the HydroBase observational dataset (Curry 1996).

To the south of the subpolar gyre region, a feature common to the observations and the hindcast is the narrow region of marked warming between $35^{\circ} \mathrm{N}$ and $40^{\circ} \mathrm{N}$. In the observations, the feature has a maximum value of $0.26^{\circ} \mathrm{C} /$ decade and penetrates from the surface down to $1,000 \mathrm{~m}$. The long-term hydrographic record at Bermuda indicates that on the western side of the basin, the warming was a feature at greater depth between 1,500 and 2,500 $\mathrm{m}$ (Curry et al. 1998). In the hindcast, the feature only penetrates to $700 \mathrm{~m}$, but has a larger maximum magnitude of $0.30^{\circ} \mathrm{C} /$ decade. The warming trend in the subtropics is most enhanced in the top $250 \mathrm{~m}$ of both the observations and the hindcast, although the trend is much
Fig. 3 Trend $\left({ }^{\circ} \mathrm{C} /\right.$ decade $)$ of zonally averaged temperature in the Atlantic Ocean for 19582001. N112 model hindcast (a) and EN3v1c observational dataset (b). c Zonal average of the number of observations in each $1.25^{\circ} \times 1.25^{\circ}$ grid cell of the EN3v1c dataset for the Atlantic Ocean. d The same as $\mathbf{c}$, but scaled to indicate number of observations for every $10-\mathrm{m}$ depth of each grid cell
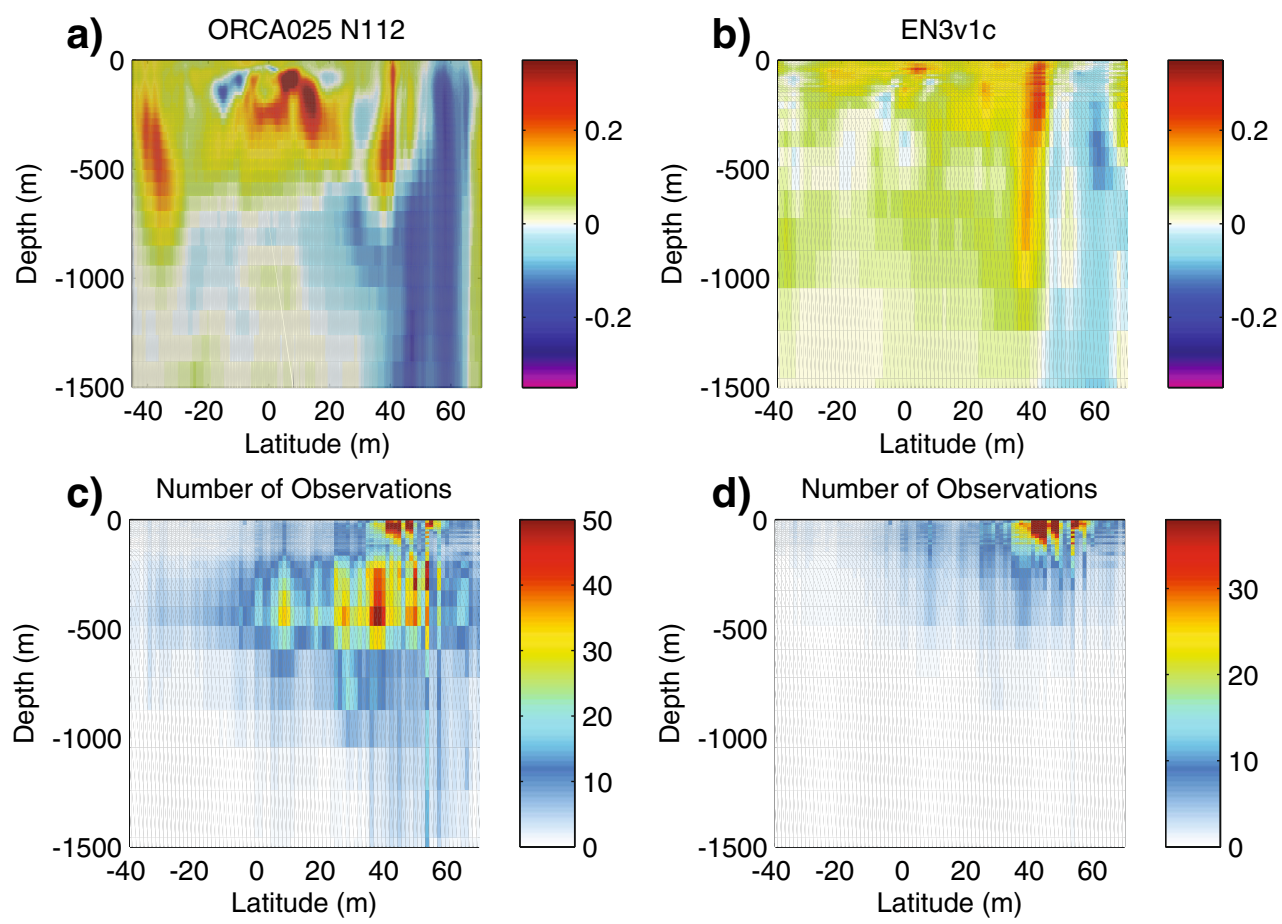
more pronounced in the model integration. This difference may be indicative of the fact that the subsurface observation density declines rapidly south of $20^{\circ} \mathrm{N}$. A further discrepancy is the region of cooling of up to $0.13^{\circ} \mathrm{C}$ between $10^{\circ} \mathrm{N}$ and $40^{\circ} \mathrm{N}$ and $600-1,200 \mathrm{~m}$ in the hindcast that is not seen in the observations. However, in this context, we note that Fig. 3c reveals that there are very few observations in this depth range. The remaining area of substantial difference between model and observations is the area of warming centred on $500 \mathrm{~m}$ and $40^{\circ} \mathrm{S}$ in the model. Again, there are very few observations in this region, so it is unlikely that EN3v1c is capable of adequately representing any trend here.

We further demonstrate the relationship between model observation agreement and observation density in Fig. 4 which shows the correlation between the modelled and observed annual zonally averaged Atlantic temperature for each grid cell (in the depth-latitude direction). The value for each grid cell was then allocated to one of six bins depending on the mean number of observations found in each grid cell (e.g. $<10,>10$ but $<20$, etc.). The mean correlation for each bin is plotted in Fig. 4. The standard deviation within each bin is plotted as an error bar. Grid cells where there are a small number of observations are associated with a relatively large range of correlation values. Furthermore, there is clear evidence that the model observation agreement tends to increase with the number of observations available.

Whilst the linear temperature trends shown in Fig. 3 provide an indicator of the vertical structure of integrated temperature changes over the reanalysis era, care must be

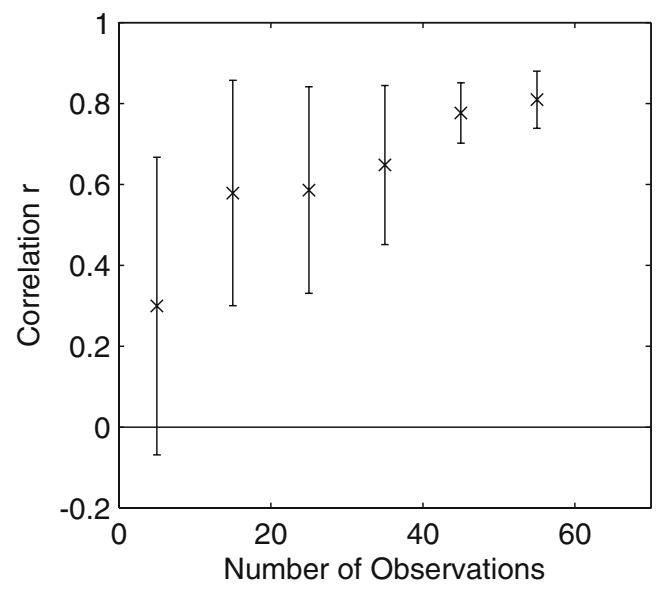

Fig. 4 Graph showing how the correlation between observed and modelled annual zonally averaged Atlantic temperature varies with the number of observations in each grid cell where the number of observations is the annual mean zonally averaged over the Atlantic basin. The results shown are the mean correlation values within bins of equal width. The error bars denote the standard deviation of the correlation value within each bin. See text for further details taken as temperature changes may not have been linear during this time. Furthermore, we wish to investigate whether the hindcast is able to capture the correct timing of the greatest changes. With this in mind, we have calculated the time evolution of the volume-averaged temperature for different regions of the North Atlantic. We show time series of the $0-500$ and $500 \mathrm{~m}$-bottom volume-averaged temperatures for the North Atlantic subpolar gyre $\left(42^{\circ} \mathrm{N}\right.$ to $\left.63^{\circ} \mathrm{N}\right)$, the North Atlantic Subtropical Gyre $\left(22^{\circ} \mathrm{N}\right.$ to $\left.42^{\circ} \mathrm{N}\right)$ and the Tropical North Atlantic $\left(0^{\circ} \mathrm{N}\right.$ to $\left.22^{\circ} \mathrm{N}\right)$ in Fig. 5 ; note that these regions are shown in Fig. 1. In each case, the climatological mean annual cycle has been removed from the data to create anomaly values for each month, and these have been averaged over 3-month intervals. Note also that the correlation coefficient $(r)$ between the respective time series is shown on the top left of each panel.

Considering the Subpolar Gyre region first, there is generally good agreement between the model and observational variability at multi-annual timescales. Observations of the temperature in the top $500 \mathrm{~m}$ show that in the mid1960 s, there was an abrupt increase of over $0.4^{\circ} \mathrm{C}$ to about $0.3^{\circ} \mathrm{C}$ above the long-term mean (Fig. 5a). This is followed by a slower uneven decline of about $0.6^{\circ} \mathrm{C}$ between the late 1960s and 1990. Between 1991 and 1999, the temperature rose quickly again to about $0.35^{\circ} \mathrm{C}$ above the mean. The model integration depicts these changes quite accurately (i.e. $r=0.93$ ). The mean temperature below $500 \mathrm{~m}$ for the region shows a similar evolution to the upper layer, with a lag of about 5 years (Fig. 5b). These changes are captured well in the model $(r=0.59)$; the only exception being the first 7-8 years of the run in which the model lies above the mean, for example by $0.2^{\circ} \mathrm{C}$ in the top $500 \mathrm{~m}$, whilst the observations indicate that the region was cooler than average during this period. The discrepancy during the early part of the run is symptomatic of a dilemma: specifying initial conditions that are both well spun-up and also representative of observations at the start time. The integration analysed here is reasonably well spun-up in that the model temperature drift is not significant, but with the drawback that these initial conditions represent the end 2001 state, which is anomalously warm in the Subpolar Gyre region, rather than a close approximation to 1958 observations. Finally, note that at short timescales, the observations show higher variance than the model; this may be an effect of undersampling arising from the low observation frequency in some areas.

Turning to the Subtropical Gyre region, good agreement is again found for the top $500 \mathrm{~m}$ (Fig. 5c). Both model and observations show a temperature decrease from 1960 to the early 1970s followed by a marked increase in temperature of about $0.4^{\circ} \mathrm{C}$ to near the long-term mean temperatures from the early 1980s until about 1990 . Subsequently, the observations show a warming of up to $0.3^{\circ} \mathrm{C}$ which is also 
Fig. 5 Time series of volumeaveraged temperature $\left({ }^{\circ} \mathrm{C}\right)$ for the top $500 \mathrm{~m}$ and from $500 \mathrm{~m}$ to bottom of North Atlantic subpolar gyre (a, b); North Atlantic Subtropical Gyre (c, d); and Tropical North Atlantic $(\mathbf{e}, \mathbf{f})$. The time series is of 3-month averages with the mean annual cycle removed. The latitudes of the regions are defined in the text and depicted in Fig. 1a. Blue lines EN3vc1 observations; red lines N112 model hindcast. The correlation coefficients for the respective time series are shown on the top left of each panel a)

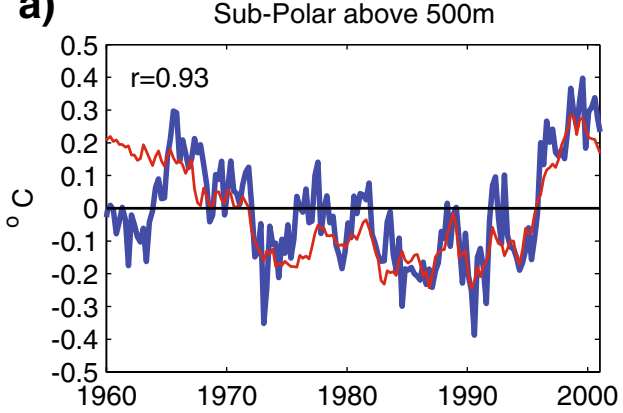

b)

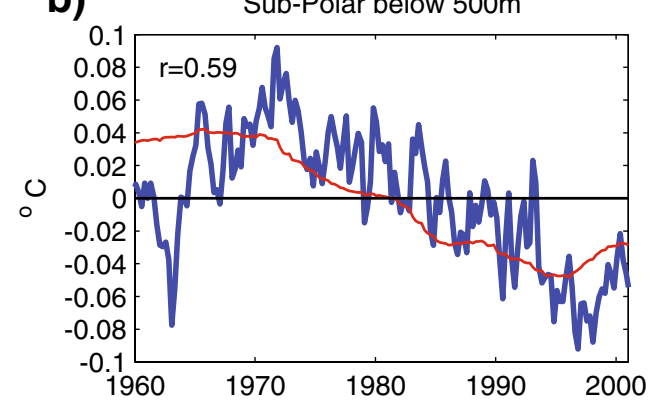

c)
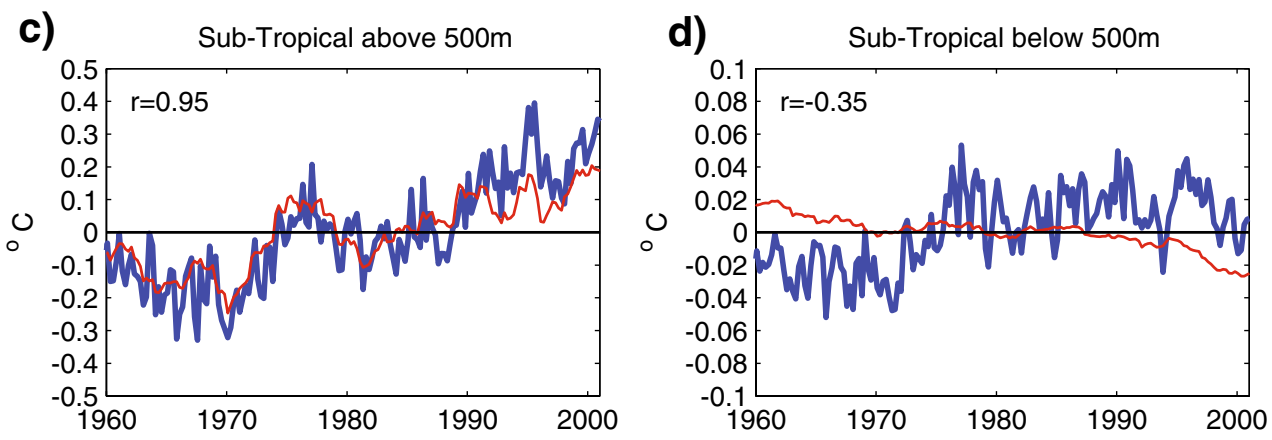

e)

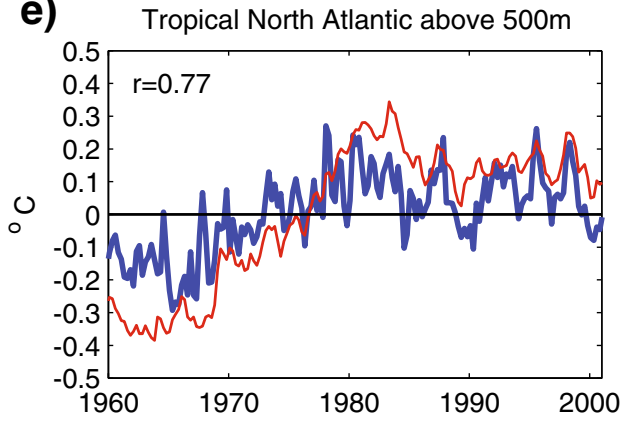

\section{f)}

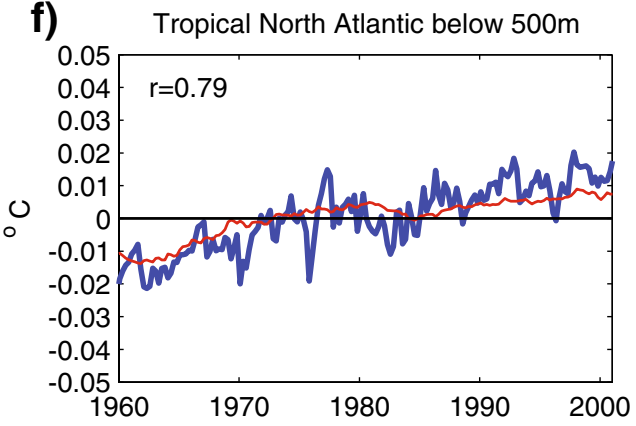

present with a lower amplitude of about $0.2^{\circ} \mathrm{C}$ in the model by the year 2000 . In contrast to the top $500 \mathrm{~m}$ where the correlation coefficient between model and observations is $r=0.95$, the model and observations of the volumeaveraged temperature below $500 \mathrm{~m}$ show opposite trends $(r=-0.35$, see Fig. 5d). Note the difference in scales between Fig. 5c, d, with the signal in the layer below $500 \mathrm{~m}$ being a small warming from 1958 to 2001 of about $0.05^{\circ} \mathrm{C}$ in the observations and a cooling by about the same amount in the model. Given the weakness of the trends and the lack of observations at depth (Fig. 3c), it is not clear how much significance should be attached to this difference.

The model simulation of the top $500 \mathrm{~m}$ volume-averaged temperature in the Tropical North Atlantic region again shows reasonably good agreement $(r=0.77)$ with the observations, although not as close as in the Subtropical region, having an increase of about $0.5^{\circ} \mathrm{C}$ between 1970 and 1980 (Fig. 5e). The post-1980 fluctuations are also largely in phase, although slightly offset. As was the case with the Subpolar region, the model temperature is significantly different from the observations in the first 7 years of the hindcast. In contrast to the subtropics, the model observation agreement for the mean temperature below $500 \mathrm{~m}$ is good throughout the run $(r=0.79$, see Fig. 5f). In particular, the near-linear observational increase of about $0.03^{\circ} \mathrm{C}$ is well captured in the model, albeit slightly underestimated. As in the other regions, the higher frequency variability in the observations is not seen in the model hindcast.

Summarising the comparison between the model hindcast and observations, the model provides a good depiction of the North Atlantic temperature evolution in regions well sampled by the observational dataset. The time and the magnitude of simulated temperature changes correspond well with EN3v1c in the three subregions considered in detail. The EN3v1c temperature trends in the South Atlantic tend to show less variability than the model, but this may reflect the lack of data in this region and the fact that the objective analysis relaxes to climatology in the absence of observations. With these caveats in mind, we now use the 
hindcast to study the causes of the Atlantic temperature changes over the past 50 years.

\subsection{Mean meridional ocean heat transport}

We first consider the properties of the mean meridional heat

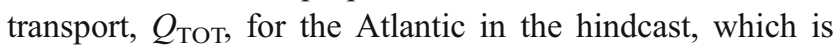
shown in Fig. 6a. It has been calculated at a given latitude, $\theta$, as follows:

$Q_{\text {TОT }}(\theta)=C_{p} \rho_{0} \sum_{x_{2}}^{x_{1}} \sum_{z_{b}}^{z_{0}}(v T) \Delta z \Delta x$

where $v$ is the meridional velocity, $T$ is the corresponding ocean temperature, $C_{\mathrm{p}}$ and $\rho_{0}$ are specific heat capacity and density of seawater, respectively (taking constant values), $\Delta z$ is the thickness (m) of a given model grid cell, $\Delta x$ is the distance (m) of the grid cell side in the $x$ direction, $x_{1}$ and $x_{2}$ are the eastern and western boundaries of the Atlantic basin, and $z_{0}$ and $z_{\mathrm{b}}$ are the depths of the top and bottom of the ocean. The variation with latitude and the magnitude of the OHT are broadly similar to other estimates shown in Fig. 6a, although the magnitude tends to be at the low end of the range. In particular, the model heat transport is within the error bars of heat transport estimates from hydrographic sections at $30^{\circ} \mathrm{S}, 8^{\circ} \mathrm{N}$ and $14^{\circ} \mathrm{N}$, but is slightly weaker than that reported at $11^{\circ} \mathrm{S}$ and $26^{\circ} \mathrm{N}$ (see Table 1 for references). In addition, over much of the basin, the model mean heat transport is very similar to the estimate of Grist and Josey (2003) and smaller by $0.2-0.3 \mathrm{PW}$ than the estimate of Trenberth and Caron (2001).
The contributions to meridional ocean heat transport from the meridional overturning circulation (MOC) and from the gyre circulation are also included in Fig. 6a. They have been calculated in the manner of Bryden and Imawaki (2001). The MOC component of the heat transport, $Q_{\text {MOC }}$, is defined as:

$Q_{\mathrm{MOC}}(\theta)=C_{p} \rho_{0} \sum_{z_{\mathrm{b}}}^{z_{0}} L(z, \theta) \bar{v} \bar{T} \Delta z$

where overbars indicate zonal averages at each model depth and latitude and $L(z, \theta)$ is the corresponding ocean basin width at latitude $\theta$ and depth $z$. The gyre component, $Q_{\mathrm{GYRE}}$, is defined as:

$Q_{G Y R E}(\theta)=\sum_{z_{b}}^{z_{0}} \sum_{x_{2}}^{x_{1}} C_{p} \rho_{0} v^{\prime} T^{\prime} \Delta x \Delta z$

where the primes indicate deviation from the zonal average. Over large latitude ranges of the basin, the MOC is the dominant contribution to ocean heat transport. This is particularly the case between the Equator and $30^{\circ} \mathrm{N}$ where the MOC component is within one standard deviation of the mean total heat transport. North of $30^{\circ} \mathrm{N}$, the MOC component decreases whilst the gyre component increases. By $43^{\circ} \mathrm{N}$, the gyre component is as large as the MOC contribution, and from $50^{\circ} \mathrm{N}$ until $65^{\circ} \mathrm{N}$, the mean heat transport is almost completely attributable to the gyre component. In this context, it is emphasised that at subtropical latitudes, the Gulf Stream is returning water at a similar temperature as southward wind-driven interior
Fig. 6 Atlantic Meridional Ocean Heat Transport $(O H T)$ from the model hindcast 19582001 as a function of latitude: mean (a) and standard deviation (b). Red line is the total transport, green line is the MOC component and blue line is the gyre component. a Also includes estimates of mean Atlantic transport from Trenberth and Caron (2001) (grey line), Grist and Josey (2003) (black line) and hydrographic sections (black crosses, see Table 1 for details). Thin red lines are \pm 1 standard deviation of the total heat transport a)

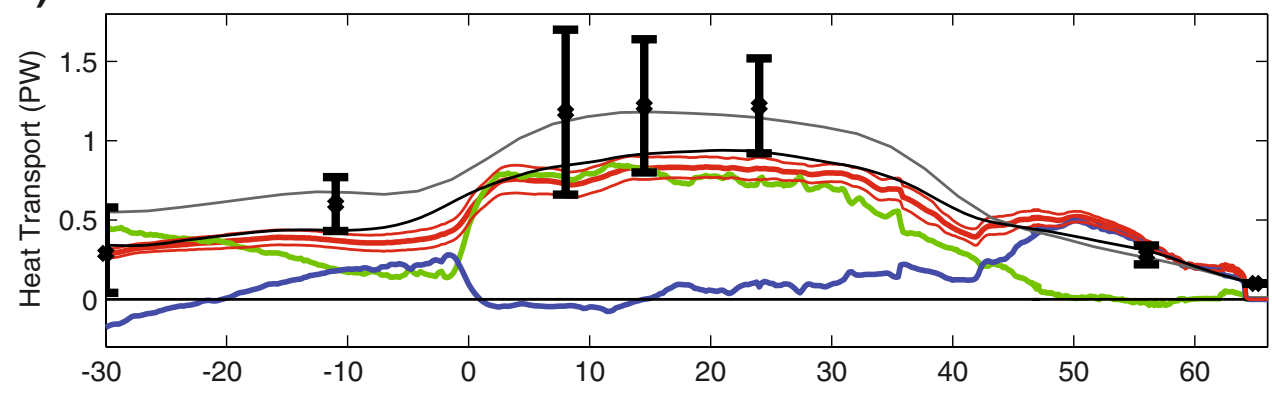

b) Atlantic Heat Transport - std 1958-2001

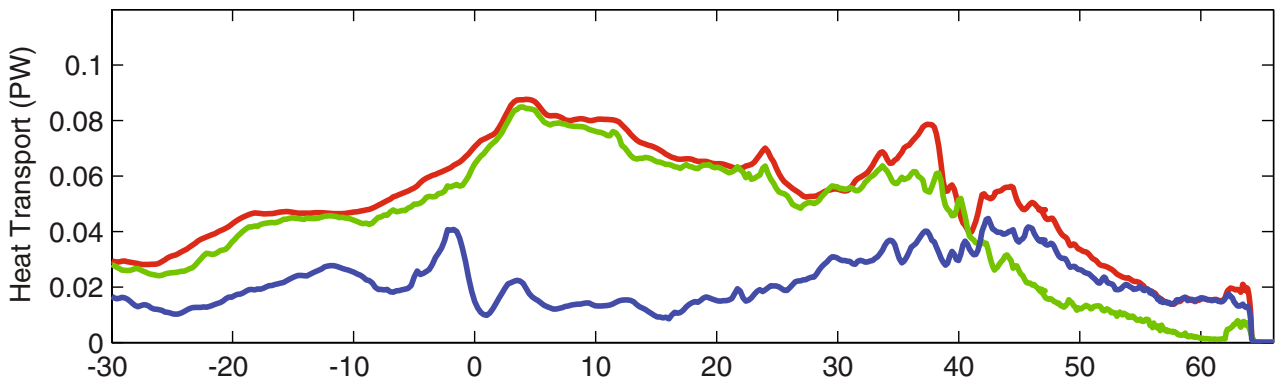


Table 1 Hydrographic measurements of the heat transport used in Fig. 5

\begin{tabular}{lll}
\hline Section & Heat transport (PW) & Reference \\
\hline $65^{\circ} \mathrm{N}$ Atlantic & 0.1 & Aagaard and Greisman (1975) \\
CONVEX Atlantic (near $\left.56^{\circ} \mathrm{N}\right)$ & $0.28 \pm 0.06$ & Bacon (1997) \\
$24^{\circ} \mathrm{N}$ Atlantic & $1.20 \pm 0.26$ & Lavin et al. (1998) \\
$14^{\circ} \mathrm{N}$ Atlantic & $1.22 \pm 0.42$ & Klein et al. (1995) \\
$8^{\circ} \mathrm{N}$ Atlantic & $1.18 \pm 0.52$ & Klein et al. (1995) \\
$11^{\circ} \mathrm{S}$ Atlantic & $0.60 \pm 0.17$ & Speer et al. (1996) \\
$30^{\circ} \mathrm{S}$ Atlantic & $0.29 \pm 0.29$ & Holfort and Siedler (2001) \\
\hline
\end{tabular}

flow, whilst north of $43^{\circ} \mathrm{N}$, there is a large temperature difference between the northward flow in the North Atlantic Current and the southward flow in the East Greenland and Labrador Currents. Apart from the North Atlantic subpolar gyre, the only other region where the gyre contribution is significant is between $10^{\circ} \mathrm{S}$ and the Equator where the gyre and MOC components contribute about equally to the total heat transport.

The standard deviation of the component and total meridional heat transports, calculated from the OHT values for each individual year in the model hindcast, are shown in Fig. $6 \mathrm{~b}$ as a function of latitude. As may be expected, the pattern of the latitudinal variation of the standard deviation for the MOC component is quite similar to the latitudinal variation of the mean transport. For example, the standard deviation is strongest (0.06-0.08 PW) between about $5^{\circ} \mathrm{N}$ and $38^{\circ} \mathrm{N}$, whilst north of this latitude, it decreases steadily to near zero at $60^{\circ} \mathrm{N}$. The standard deviation of the gyre component becomes greater than that of the MOC component north of about $41^{\circ} \mathrm{N}$. However, the latitudinal variation of the standard deviation of the gyre component does have a different shape from the mean gyre transport. The maximum of the gyre standard deviation is part of a broader peak than the gyre mean, and its maximum value is at $42^{\circ} \mathrm{N}$, some $10^{\circ}$ south of the peak for the mean gyre transport. This difference reflects the fact that the strongest mean gyre transport appears to be in the centre of the North Atlantic subpolar gyre, whilst the variability is greatest in the inter-gyre exchange region between the North Atlantic subpolar and subtropical gyres. The gyre component also has a peak of comparable magnitude $(0.04 \mathrm{PW})$ near $3^{\circ} \mathrm{S}$, the location of the South Atlantic maximum in northward heat transport by the gyre. We note that in this region, the 'gyre' component, by its definition (Eq. 3), will include the longitudinal variation in the Ekman transport. On the southern side of the Intertropical Convergence Zone, this may exhibit considerable interannual variability.

To summarise, the MOC dominates the meridional heat transport over most of the Atlantic basin. However, the influence of the gyre circulation increases with latitude, and north of about $40^{\circ} \mathrm{N}$, it becomes the most important mechanism. The only other area where the gyre contribu- tion has comparable importance to the MOC is the southern equatorial region.

\subsection{Temporal evolution of ocean heat content}

\subsubsection{Heat content calculation}

In this section, we consider the year-to-year changes in ocean heat content $(\mathrm{OHC})$ within the three regions of the North Atlantic previously defined and the relative contribution of different terms to the changes. For each region, we explicitly calculate the model ocean heat content anomaly $\left(\mathrm{OHC}^{*}\right)$ at each monthly time step $(t)$ as follows:

$$
\begin{aligned}
\mathrm{OHC}^{*}(t)= & C_{p} \rho_{0} \sum_{z_{\mathrm{b}}}^{z_{0}} \sum_{y_{\mathrm{s}}}^{y_{\mathrm{N}}} \sum_{x_{2}}^{x_{1}} T^{*}(t) \Delta x \Delta y \Delta z \\
& +C_{\mathrm{p}} \rho_{0} \sum_{y_{\mathrm{s}}}^{y_{N}} \sum_{x_{2}}^{x_{1}} T^{*}\left(z_{0}, t\right) H_{\mathrm{SSH}}^{*}(t) \Delta x \Delta y
\end{aligned}
$$

where in addition to terms previously defined, $y_{\mathrm{N}}$ and $y_{\mathrm{S}}$ represent the northern and southern boundaries of the region, respectively, $\Delta y$ is the length of each grid cell in the direction of the $y$ coordinate, and $T^{*}, H^{*}{ }_{\mathrm{SSH}}$ are the model ocean temperature and sea surface height anomalies (i.e. departures from climatological monthly means). The asterisks indicate departures from the long-term mean at each grid point.

\subsubsection{North Atlantic subpolar gyre}

The temporal evolution of the North Atlantic subpolar gyre heat content anomaly, $\mathrm{OHC}^{*}$, is shown in Fig. 7a where, for clarity, we have averaged the monthly anomalies for each individual year. The figure reveals a relatively stable positive heat content anomaly from about 1960 until the early 1970s. There is then a sharp decline, followed by values close to zero until the early 1980s and a further sudden drop resulting in a negative heat content anomaly which persists until the mid-1990s. This is followed by a return to conditions near the long-term mean in the early 2000s. 
Fig. 7 a Time series of full-depth ocean heat content anomaly, $\mathrm{OHC}^{*}(\mathrm{~J})$, in the North Atlantic subpolar gyre. b Anomalous annual change in heat content, $\triangle \mathrm{OHC}^{*}(\mathrm{~J}$, black bars), and the contribution to this change from anomalous surface heat flux (blue bars), anomalous ocean heat transport convergence (red bars) and residual terms (cyan bars). c Ocean heat convergence for the North Atlantic Subpolar Gyre region (solid red line) and corresponding heat transports at the southern (dashed) and northern (dot-dashed) boundaries of the domain (W). d Anomalies of the MOC (solid) and gyre (dot-dashed) components of heat transport (W) at the southern boundary
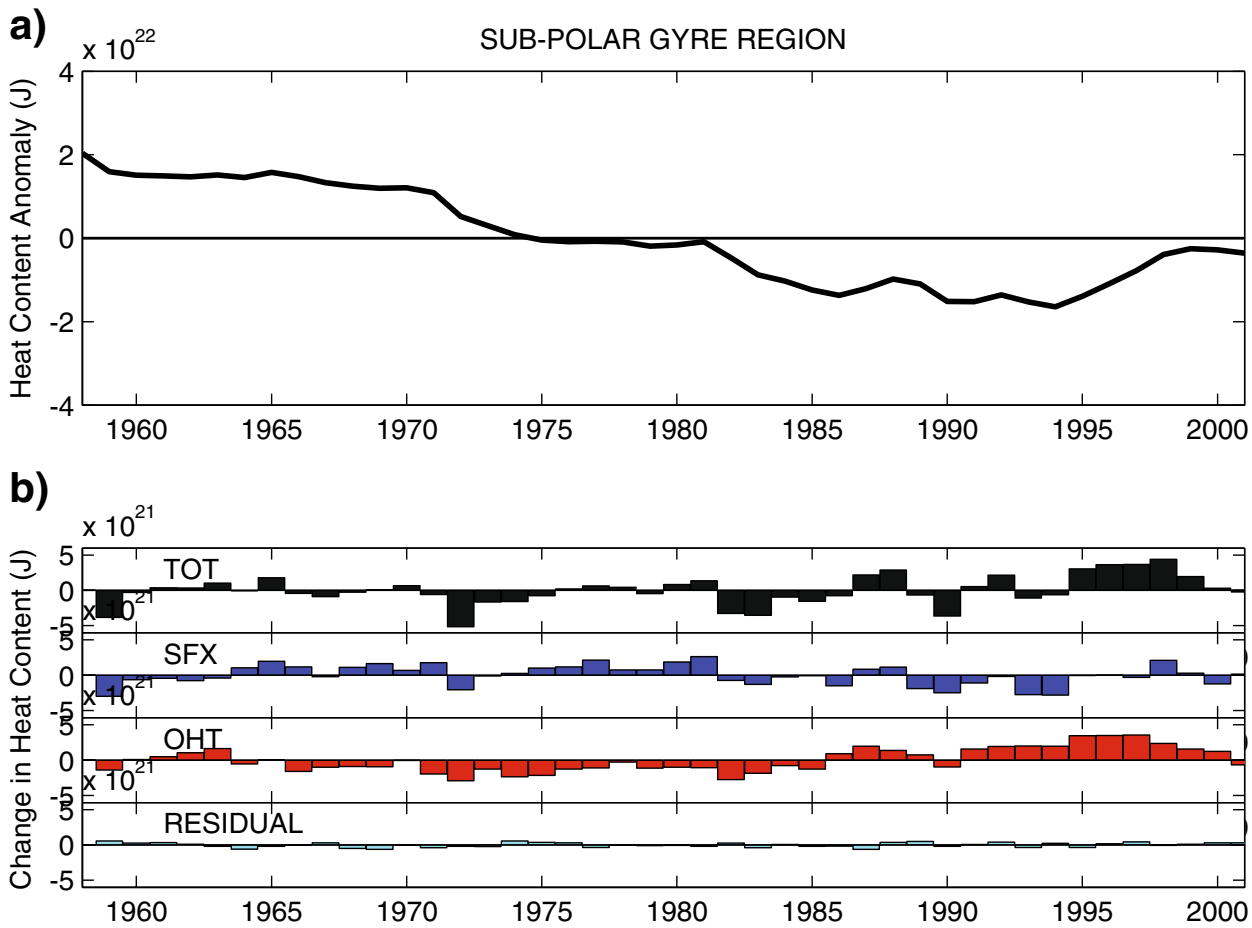

c) $\times 10^{14}$

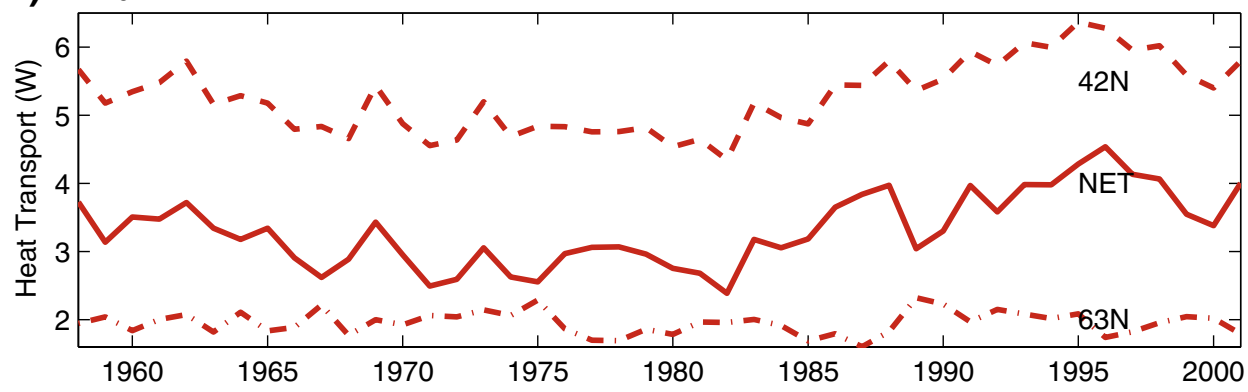

d)

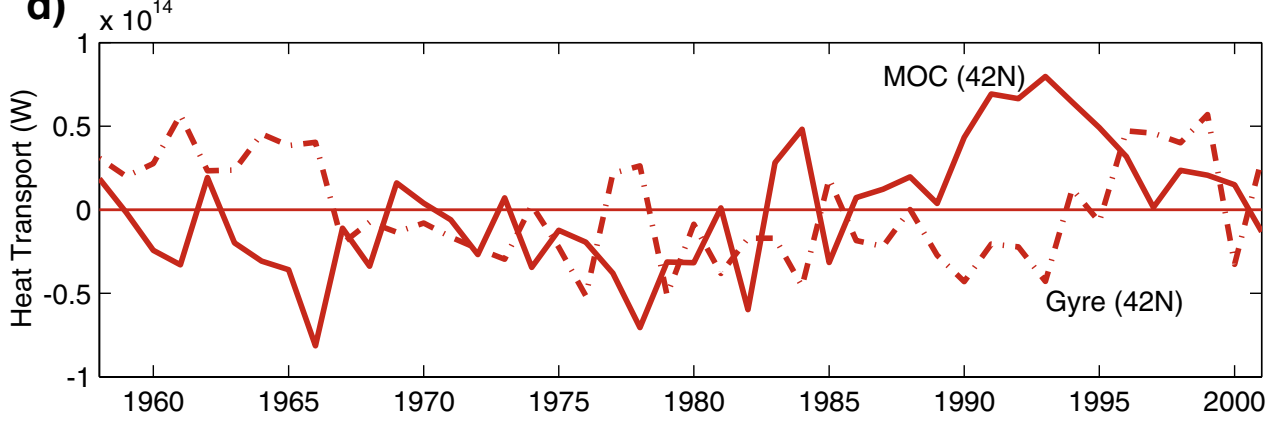

We now consider the anomalous change in $\mathrm{OHC}^{*}$ from one year to the next which we refer to as $\triangle \mathrm{OHC}^{*}$. This is shown as black bars in Fig. $7 \mathrm{~b}$, together with the contributions to this change from the energy gain/loss due to anomalous area-integrated surface heat flux (blue bars) and anomalous ocean heat transport convergence (red bars). The surface flux and OHT convergence terms should together account for the total change. Positive (negative) values of $\triangle \mathrm{OHC}^{*}$ indicate ocean warming (cooling) relative to the previous year. The figure shows the extent to which anomalies in atmospheric fluxes and/or ocean heat transport convergence are responsible for the heat content change relative to the previous year. Although there are some years (1964-66, 1977-81, 1989-1991, 1993-4) when the anomalous surface heat flux is the dominant mechanism of heat content change, sustained multiyear heat transport convergence anomalies tend to have a greater influence. Considering the whole time series, the correlation of $\triangle \mathrm{OHC}^{*}$ with the 
convergence anomalies is higher with the ocean component $(r=0.75)$ than with the surface flux component $(r=0.53)$. In particular, $57 \%$ of the ocean heat content reduction between 1982 and 1986 and 94\% of the increase between 1995 and 1999 is due to the convergence anomalies. Finally, we show the residual term $\left(\triangle \mathrm{OHC}^{*}\right.$ minus the anomalies in ocean heat transport convergence and surface heat flux), in the fourth panel of Fig. $7 \mathrm{~b}$. The residuals are generally close to zero, and this indicates that we are able to close the regional heat budget and accurately attribute changes in the heat content to either anomalous surface fluxes or anomalous convergence of heat transport. A non-zero residual is inevitable due to high-frequency eddy fluxes and diffusion in regions of strong temperature and salinity gradients.

Considering the ocean heat transport component in more detail, the total ocean heat transport anomaly and the individual transports at the southern and northern boundaries of the domain are shown in Fig. 7c. It is clear that most of the variability in the subpolar gyre heat transport convergence is due to the variability in transport at the southern boundary $\left(42^{\circ} \mathrm{N}\right)$ as opposed to the northern boundary $\left(63^{\circ} \mathrm{N}\right)$. Specifically, the correlation of subpolar gyre heat transport convergence with the $42^{\circ} \mathrm{N}$ transport is $r=0.95$ compared with $r=-0.22$ for the transport at $63^{\circ} \mathrm{N}$. We further separate the heat transport variability at $42^{\circ} \mathrm{N}$ into the anomalies of the MOC and gyre components in Fig. 7d. There is a tendency for the MOC and gyre components to be opposite in sign. However, when this is not the case (in particular 1972-74 and 1995-1999), large heat content changes occur. Prior to 1990, the contribution from the MOC component was either anomalously weak or around the mean. For about 6 years from 1990, there was a sustained anomalously large contribution from the MOC before it returned to near-average levels between 1996 and 2000. However, as the MOC component was decreasing, the gyre component increased and remained anomalously strong for 4 years. It is thus a combination of MOC and gyre anomalies which result in the warming towards the end of the model run.

The ability to achieve near closure of the regional heat budgets, and thus accurately account for the relative contributions to heat content change from ocean and atmosphere, is an advantage of performing the calculations on full-depth ocean heat content. However, in principle, the same calculation can be carried out on any sub-layer of the ocean. By way of illustration in Fig. 8a, b, we have calculated $\mathrm{OHC}^{*}, \triangle \mathrm{OHC}^{*}$ and the contributing terms for the top $500 \mathrm{~m}$ of the same North Atlantic Subpolar Gyre region. In this upper layer, the evolution of $\mathrm{OHC}^{*}$ shows a similar pattern to the full-depth case, albeit with greater interannual variability. Similarly, the $\Delta \mathrm{OHC}^{*}$ time series (black bars in Fig. 8b) is very similar (although not identical) to the full-depth case, thus confirming that most of the heat content changes are occurring in the top $500 \mathrm{~m}$. In terms of the relative contribution of surface fluxes and ocean heat transport convergence, it remains the case that in the top $500 \mathrm{~m}$, the OHT contribution is more strongly
Fig. 8 a Time series of ocean heat content anomaly, $\mathrm{OHC}^{*}(\mathrm{~J})$, for the top $500 \mathrm{~m}$ of the North Atlantic subpolar gyre. b Anomalous annual change in heat content, $\triangle \mathrm{OHC}^{*}(\mathrm{~J}$, black bars), and the contribution to this change from anomalous surface heat flux (blue bars), anomalous ocean heat transport convergence (red bars) and residual terms (cyan bars)

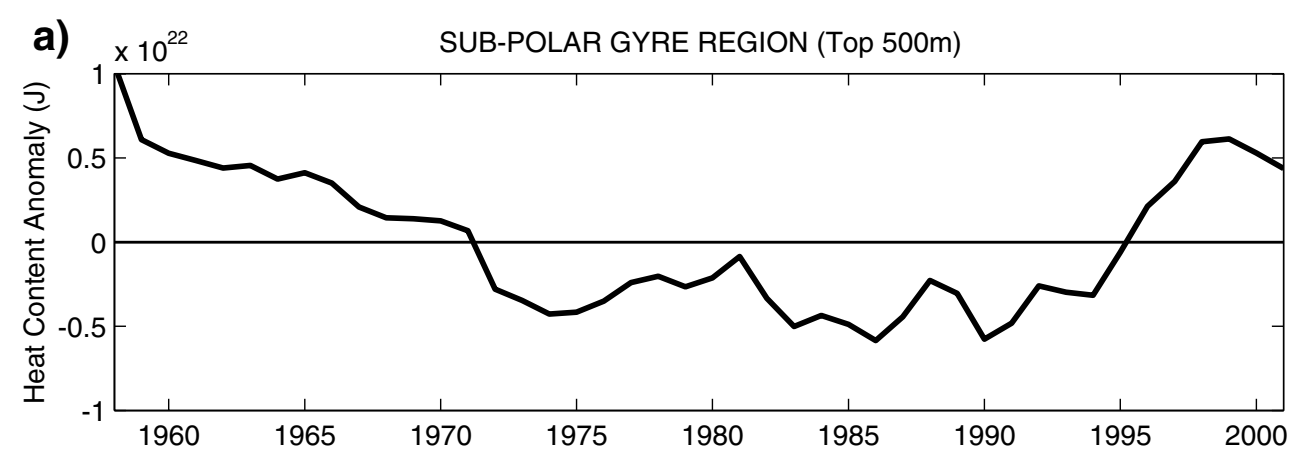

b)

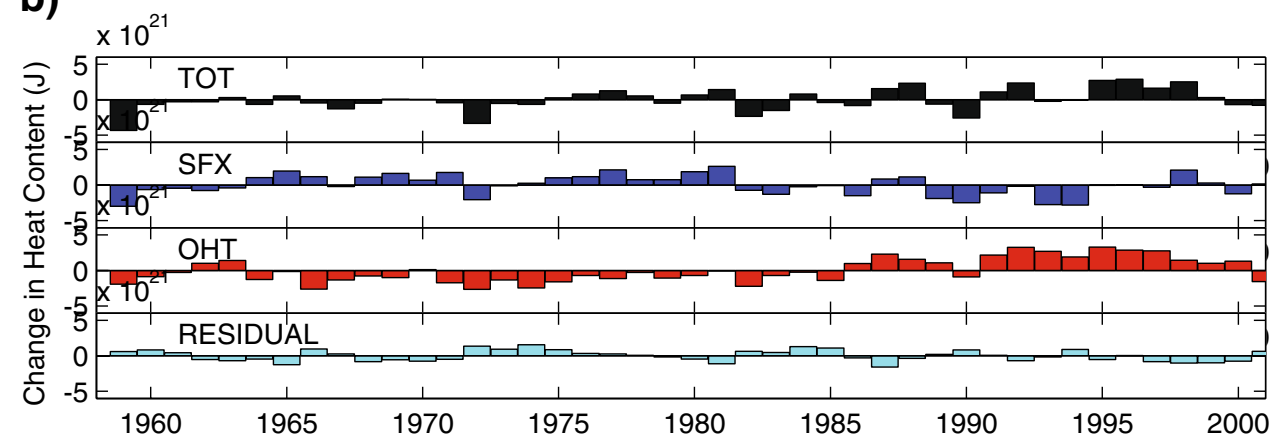


correlated $(r=0.67)$ with the total heat content change than the surface flux contribution $(r=0.54)$, although the difference between the two is not as great as is the case in the full-depth ocean case. The most noticeable difference between the full-depth and top 500-m analysis is that in the case of the top $500 \mathrm{~m}$, the residual terms are no longer negligible. This reflects the fact that there is a vertical heat exchange between the top $500 \mathrm{~m}$ and below. The temporal variation of the residual term suggests that there may be a signature of interannual or decadal variability in this vertical heat exchange. Although the foci of this study are full-depth ocean heat budgets, the possibility of using the model to examine the causes of variability in vertical exchanges warrants further investigation.

\subsubsection{North Atlantic subtropical gyre}

Time series of subtropical gyre heat content anomaly, $\mathrm{OHC}^{*}$, and its anomalous year-on year change, $\triangle \mathrm{OHC}^{*}$, are shown in Fig. 9a, b, respectively. As noted in Section 3.1, the large changes seen in the subpolar gyre are not evident in the subtropical gyre, which exhibits no major long-term variations. The main period of notable heat content change occurs during the 1970s. First, from 1970 to about 1975, there is an increase in heat content, which is attributable to anomalously strong ocean heat transport convergence (Fig. 9b). This is followed by a period of cooling, which lasts until the early 1980s, that is mainly due to anomalously weak heat transport convergence, with an additional contribution from stronger than normal surface heat loss.

The total ocean heat convergence is plotted in Fig. 9c along with the ocean heat transports at $42^{\circ} \mathrm{N}$ and $22^{\circ} \mathrm{N}$. Note that the calculated ocean convergence included heat transport through the Gibraltar Strait, but this small term is not plotted here. The variability of heat transport is about $20 \%$ greater at $22^{\circ} \mathrm{N}$ (standard deviation of $6.4 \times 10^{13} \mathrm{~W}$ ) than it is at $42^{\circ} \mathrm{N}$ (standard deviation of $5.3 \times 10^{13} \mathrm{~W}$ ). Prior to 1986 , the heat transport convergence may be largely explained by transport changes at $22^{\circ} \mathrm{N}(r=0.86)$. However, after 1986, the time series at $22^{\circ} \mathrm{N}$ and $42^{\circ} \mathrm{N}$ vary in a more similar manner $(r=0.41$ compared to $r=-0.13$ before 1986). This partly cancels out the influence of $22^{\circ} \mathrm{N}$ transport on convergence as additional transport into the North Atlantic Subtropical Gyre region across $22^{\circ} \mathrm{N}$ is matched by increased transport across the northern boundary of the region. When we consider the components of the heat transport at $22^{\circ} \mathrm{N}$, it is clear that there is a much greater contribution from the MOC than the gyre. In addition, as we compare Fig. 9d with b, it is evident that a significant portion of the Subtropical Gyre region heat content variability can be explained by the variability in the MOC at $22^{\circ} \mathrm{N}$ alone. Specifically, between 1959 and 1987 , the correlation between the subtropical gyre change in heat content and the MOC heat transport at $22^{\circ} \mathrm{N}$ is $r=0.65$. After 1987, this correlation breaks down $(r=-0.14)$ as the transport at $42^{\circ} \mathrm{N}$ becomes more important.

\subsubsection{Tropical North Atlantic}

A time series of $\mathrm{OHC}^{*}$ for the Tropical North Atlantic region is shown in Fig. 10a. It reveals an initial cooling until the early 1960 s, followed by a prolonged warming to the early 1980s and relatively constant values thereafter. The anomalous year-on-year change, $\Delta \mathrm{OHC}^{*}$ and its components, are shown in Fig. 10b. It can be seen that the cooling between 1958 and 1963 is predominantly associated with greater than normal ocean heat transport divergence (note that in contrast to the other two regions discussed above, the Tropical North Atlantic region is one of transport divergence rather than convergence). A reduction in ocean heat divergence, combined with a number of years of anomalously strong net heat flux into the ocean, results in the subsequent heat content increase. After 1980, there is substantial interannual variability in the ocean heat transport divergence with additional contributions from anomalous surface heat flux, but neither term is dominant for a sustained number of years.

The net ocean heat transport divergence, together with the transports at the northern and southern boundaries of the Tropical North Atlantic region, is plotted in time series form in Fig. 10c. For much of the integration, the transports at $0^{\circ} \mathrm{N}$ and $22^{\circ} \mathrm{N}$ are quite coherent. For example, between 1962 and 1996, the correlation between the heat transports is $r=0.65$. As a consequence, with the exception of a few years $(1958-1964,1969,1984,1988)$, the ocean heat transport convergence is relatively constant. During the period 1958-1964, the northward heat transport at the Equator is anomalously weak, whilst at $22^{\circ} \mathrm{N}$, it remains fairly constant at mean levels. It can be seen in Fig. 10d that the low transport at $0^{\circ} \mathrm{N}$ between 1958 and 1964 was due to a weaker MOC at that location. From these initial low values at the beginning of the time series, there is some evidence of a subsequent positive trend with increasing MOC serving to increase Tropical North Atlantic region heat content. However, this ceases to be the case after 1966 because MOC heat transport at the southern boundary becomes quite coherent $(r=0.61)$ with that at the northern boundary, as shown in Fig. 9d.

\subsubsection{North Atlantic synopsis}

Comparing the dominant processes in the three regions, it appears that the surface heat flux plays a relatively minor role in year-to-year changes in the Subpolar and Subtropical regions, but in the Tropical North Atlantic, its role is of similar significance to the ocean heat transport conver- 
Fig. 9 a Time series of full-depth ocean heat content anomaly, $\mathrm{OHC}^{*}(\mathrm{~J})$, in the North Atlantic Subtropical Gyre. b Anomalous annual change in heat content, $\triangle \mathrm{OHC}^{*}(\mathrm{~J}$, black bars), and the contribution from anomalous surface heat flux (blue bars), anomalous ocean heat transport convergence (red bars) and residual terms (cyan bars). c Ocean heat convergence for the North Atlantic Subtropical Gyre region (solid red line) and heat transports at the southern (dashed) and northern (dot-dashed) boundaries of domain (W). d Anomalies of the MOC (solid) and gyre (dot-dashed) components of heat transport (W) at the southern boundary a)

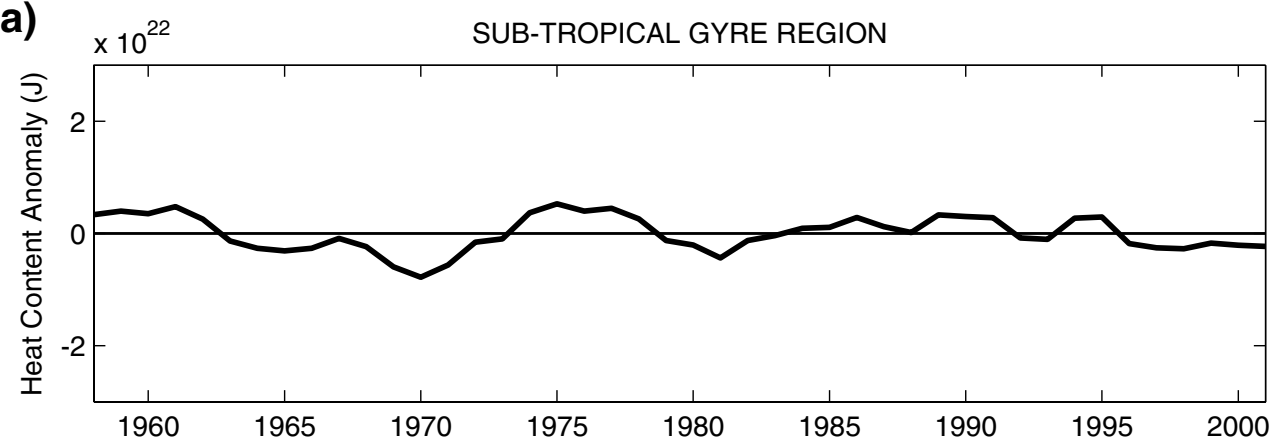

b)
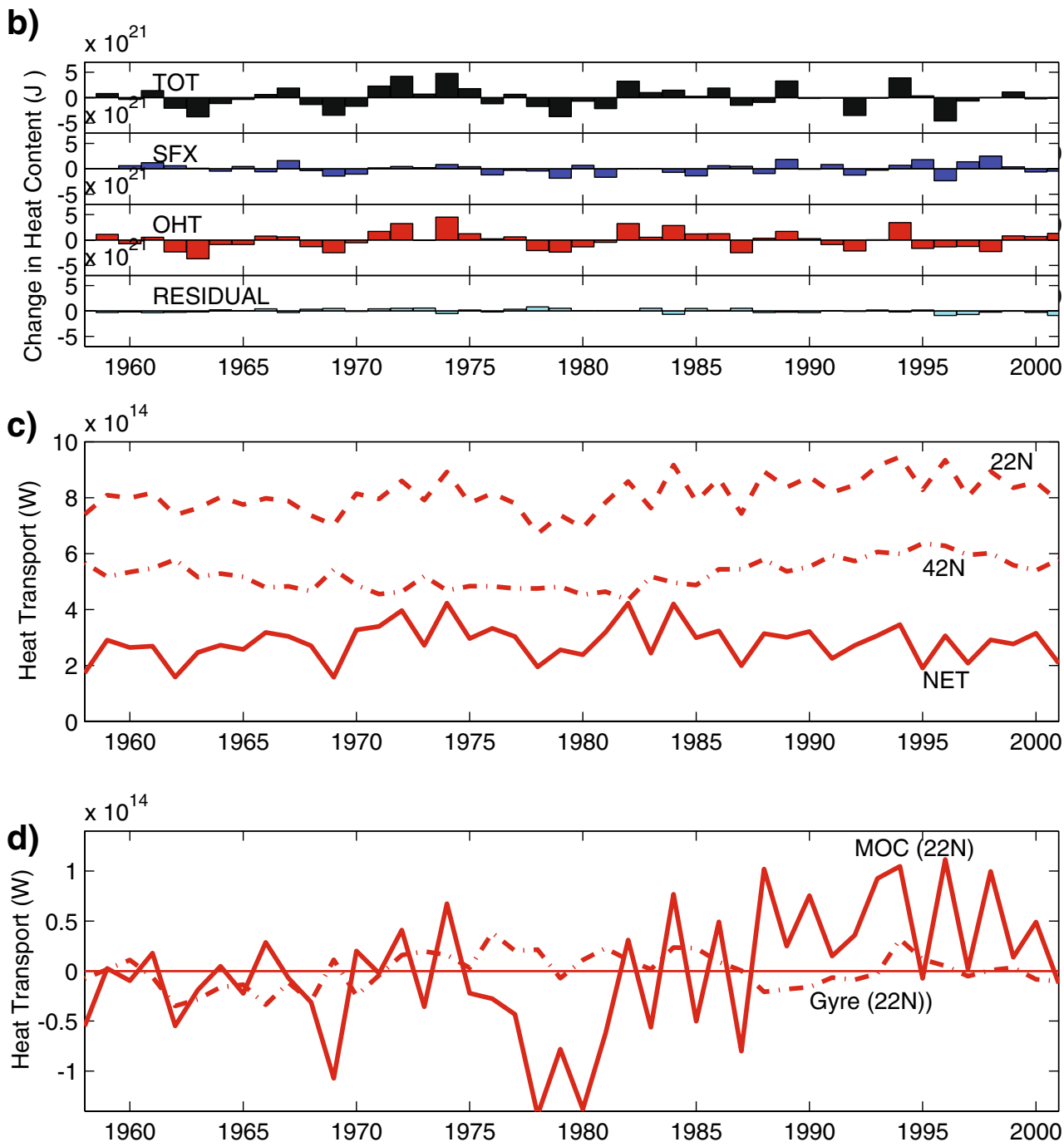

gence. We express this quantitatively in Table 2 which shows the number of years for which the surface fluxes or the ocean heat transport convergence contributed the greater amount towards the warming or cooling of the ocean. A warming or cooling year is defined as a year in which the anomalous increase or decrease in heat content was more than 0.5 of the standard deviation. In the Subpolar Gyre region, the surface heat flux is the dominant contributor to warming in only two out of the ten warming years and three out of the nine cooling years. Similarly, in the Subtropical Gyre region, the surface heat flux is the dominant contributor in 3 out of 12 warming years and 4 out of 13 cooling years. However, by the same measure in the Tropical North Atlantic, the relative roles of the surface heat flux and ocean heat transport convergence are more comparable, with the anomalous surface heat flux accounting for the larger part of the heat change in 7 out of 15 warming years and 7 out of 14 cooling years. 
Fig. 10 a Time series of full-depth ocean heat content anomaly, $\mathrm{OHC}^{*}(\mathrm{~J})$, in the Tropical North Atlantic region. b Anomalous annual change in heat content, $\triangle \mathrm{OHC}^{*}(\mathrm{~J}$, black bars), and the contribution from anomalous surface heat flux (blue bars), anomalous ocean heat transport convergence (red bars) and residual terms (cyan bars). c Ocean heat convergence for the Tropical North Atlantic region (solid red line) and heat transports at the southern (dashed) and northern (dot-dashed) boundaries of domain (W). d Anomalies of the MOC (solid) and gyre (dot-dashed) components of heat transport $(\mathrm{W})$ at the southern boundary
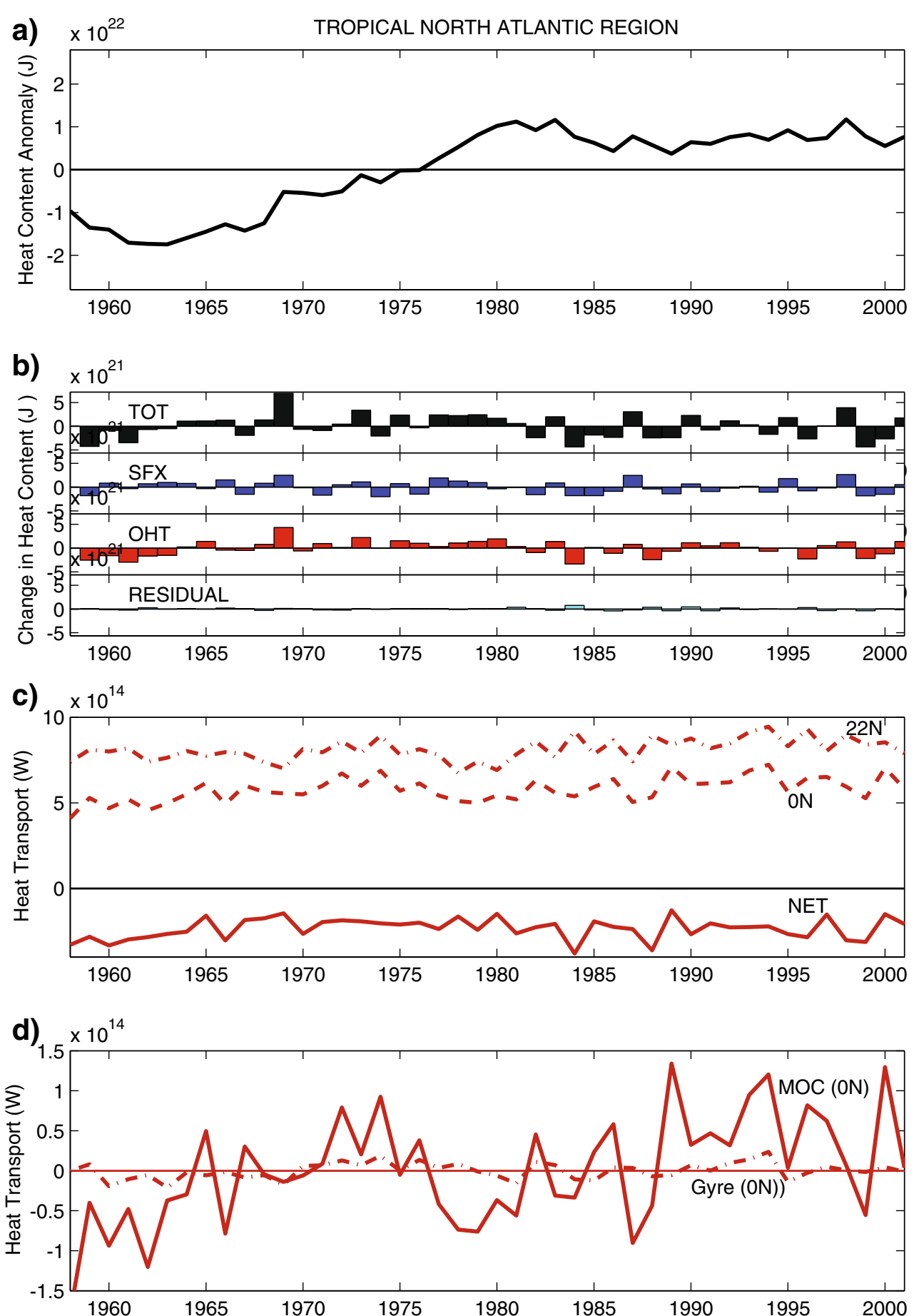

Having established that there is a greater role for surface fluxes in the ocean heat content variability in the Tropical North Atlantic than in regions to the north, we investigate if there are common factors influencing the surface fluxes during years for which they are the dominant contributor to the Tropical North Atlantic warming or cooling. In Fig. 11, we show the difference in selected model and forcing fields between the surface warming years and the surface cooling years (see Table 2).
Specifically, the difference in composites of net heat flux and surface wind speed for the warming and cooling years are shown in Fig. 11a, b, respectively. The wind speed field shows a weakening of the winds over much of the Tropical North Atlantic region by up to $1 \mathrm{~ms}^{-1}$. This leads to a reduction in sensible and latent heat loss from the ocean surface and thus the positive anomaly in the net surface heat flux (positive surface heat flux corresponds to oceanic heat gain). 
Table 2 Number of years in the 44-year model integration in which the atmospheric surface heat flux or ocean heat transport convergence makes the greater contribution to heat content change in warming (and cooling) years

\begin{tabular}{lcccc}
\hline Region & $\begin{array}{l}\text { Number of atmospheric } \\
\text { dominated warming years }\end{array}$ & $\begin{array}{l}\text { Number of ocean } \\
\text { dominated warming years }\end{array}$ & $\begin{array}{l}\text { Number of atmospheric } \\
\text { dominated cooling years }\end{array}$ & $\begin{array}{l}\text { Number of ocean } \\
\text { dominated cooling years }\end{array}$ \\
\hline Subpolar Gyre Region & $2 / 10$ & $8 / 10$ & $3 / 9$ & $6 / 9$ \\
Subtropical Gyre Region & $3 / 12$ & $9 / 12$ & $4 / 13$ & $9 / 13$ \\
Tropical North Atlantic Region & $7 / 15$ & $8 / 15$ & $7 / 14$ & $7 / 14$ \\
\hline
\end{tabular}

Note that a warming (cooling) year is defined as a year when the heat content increased (decreased) by at least half of the standard deviation of the annual heat content change

The cause of the weakening of the winds is evident in Fig. 11c which shows the warming minus cooling composite of SST (shading) and sea level pressure (contours). The global SST pattern clearly resembles El Niño. Specifically, five of the seven warming years occurred within episodes of El Niño and four out of the seven cooling years occurred during La Niña. The significance of the changes in Pacific SSTs associated with El Niño for this study is that they induce changes in the atmospheric circulation. As indicated by Fig. 11c and well documented elsewhere (e. g. Horel and Wallace 1981; Niebauer 1988), the extratropical atmospheric response to El Niño involves the strengthening and eastward shift of the Aleutian Low and the weakening of the Atlantic subtropical high-pressure system. It is the weakening of the Atlantic subtropical high that leads to a reduction in strength of the southeasterly trade winds in the region. This mechanism for El Niño influence on the temperature of the tropical Atlantic Ocean is consistent with previous findings (e.g. Enfield and Mayer 1997).

\subsection{Ocean heat transport-net heat flux relationship}

Having considered the relative contribution of surface fluxes and ocean heat transport to ocean heat content changes by region, we now examine the basin-wide evolution of ocean heat transport and its relationship with anomalies in the surface heat flux. Hovmöller plots of the zonally averaged Atlantic heat transport for the total, MOC component and gyre components are shown in Fig. 12a-c, respectively. The plots provide a latitude-based perspective on the heat transport variability, and from this, three features are noted. First, to a close approximation, the heat transport by the MOC south of $40^{\circ} \mathrm{N}$ accounts for most of the variability in the total heat transport, consistent with the earlier discussion of Fig. 6b. There are exceptions to this, such as the strongly reduced gyre circulation between $30^{\circ}$ and $40 \mathrm{~N}$ during 1964-1972, but generally, these occurrences are few and their influence modest. Second, the total heat transport and the component parts are dominated by an interdecadal signal. The total heat transport and the MOC component have elevated values in the early 1970s and
1990 s, again south of about $40^{\circ} \mathrm{N}$, with some interannual variability superimposed. The smaller gyre component is also mainly governed by interdecadal variability. Third, there is a strong tendency for latitudinal coherence in the total heat transport and MOC signal. The range of coherence usually spans the tropics $\left(23^{\circ} \mathrm{S}\right.$ to $\left.23^{\circ} \mathrm{N}\right)$, but is not constant. In particular, in the late $1970 \mathrm{~s}$ and $1990 \mathrm{~s}$, there appears to be coherence all the way from $30^{\circ} \mathrm{S}$ to $40^{\circ} \mathrm{N}$, whereas in the mid $1980 \mathrm{~s}$, the range is more limited from the Equator to $30^{\circ} \mathrm{N}$.

We finally consider the extent to which OHT anomalies can be linked to surface flux anomalies. In our analysis, the net heat flux is defined to be positive for heat gain and negative for ocean heat loss. With this sign convention, positive surface flux anomalies can arise either as a result of more heat than normal (i.e. more than the climatological monthly mean), going into the ocean at low latitudes, or less heat than normal, being lost from the ocean at high latitudes. Zonally averaged positive heat flux anomalies are also plotted as contours on Fig. 12a, b. The grey horizontal line at $27^{\circ} \mathrm{N}$ represents the climatological location of the zero net heat flux such that to the north is an area of mean ocean heat loss and the area to the south is an area of heat gain. In addition, dashed lines on either side of the solid line show $\pm 20 \mathrm{Wm}^{-2}$ and indicate a region of close to zero net heat exchange. Away from this region, an interesting pattern emerges: At low-mid latitudes $\left(30^{\circ} \mathrm{S}\right.$ to $\left.27^{\circ} \mathrm{N}\right)$, positive heat flux anomalies corresponding to increased ocean heat gain tend to coincide with anomalously strong transport to higher latitudes. This is consistent with positive tropical heat flux warming the low-latitude ocean and increasing the northward ocean heat transport.

By contrast, in the high-latitude regions of mean ocean heat loss (north of $30^{\circ} \mathrm{N}$ ), positive heat flux anomalies corresponding to reduced ocean heat loss are typically found at the northern end of bands of weakened northward ocean heat transport (e.g. in 1980). This could be indicative of reduced poleward heat transport resulting in weaker heat loss to the atmosphere. Thus, the figure suggests surface heat flux variability driving heat transport variability at low-mid latitudes and vice versa at higher latitudes. 
Fig. 11 Mean difference between years of surface Tropical North Atlantic ocean warming and surface Tropical North Atlantic ocean cooling (see text for definitions). a Surface net heat flux ( $\mathrm{W} \mathrm{m}^{-2}$ ). b $10-\mathrm{m}$ wind speed (shading, $\mathrm{ms}^{-1}$ ) and direction (vectors). c SST $\left({ }^{\circ} \mathrm{C}\right.$, shading) and sea level pressure (contours, 1-mb interval, grey lines for negative values, black lines for positive values). The northern and southern boundaries of the Tropical North Atlantic region are also indicated

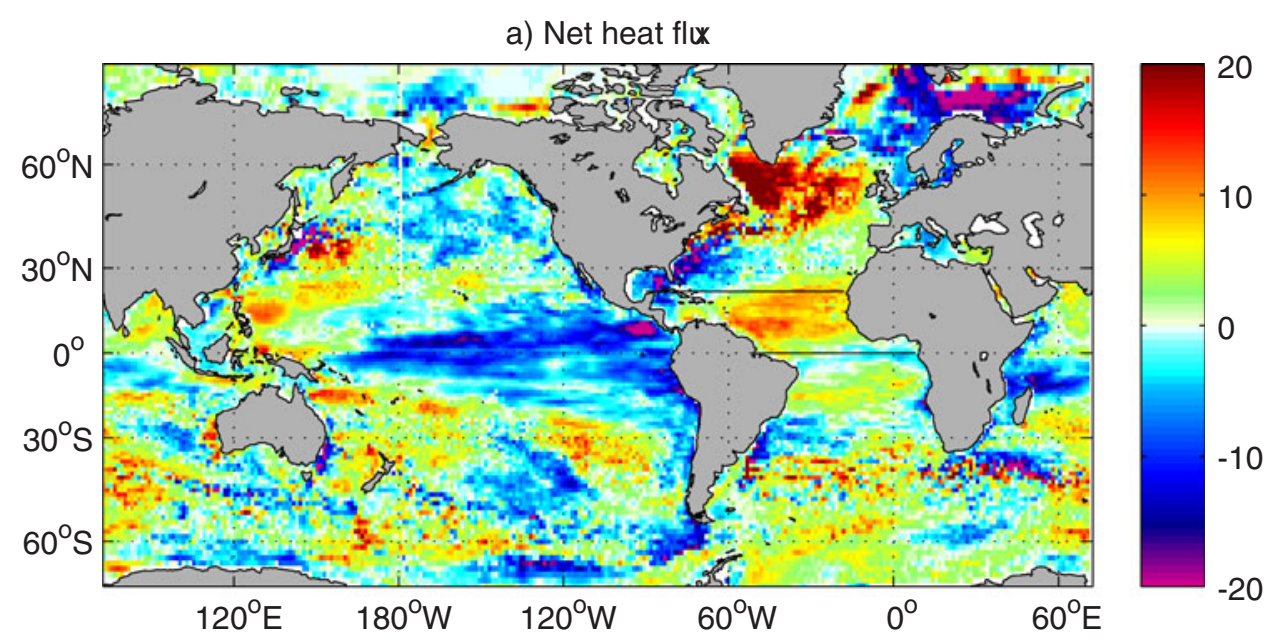

b) Surface wind
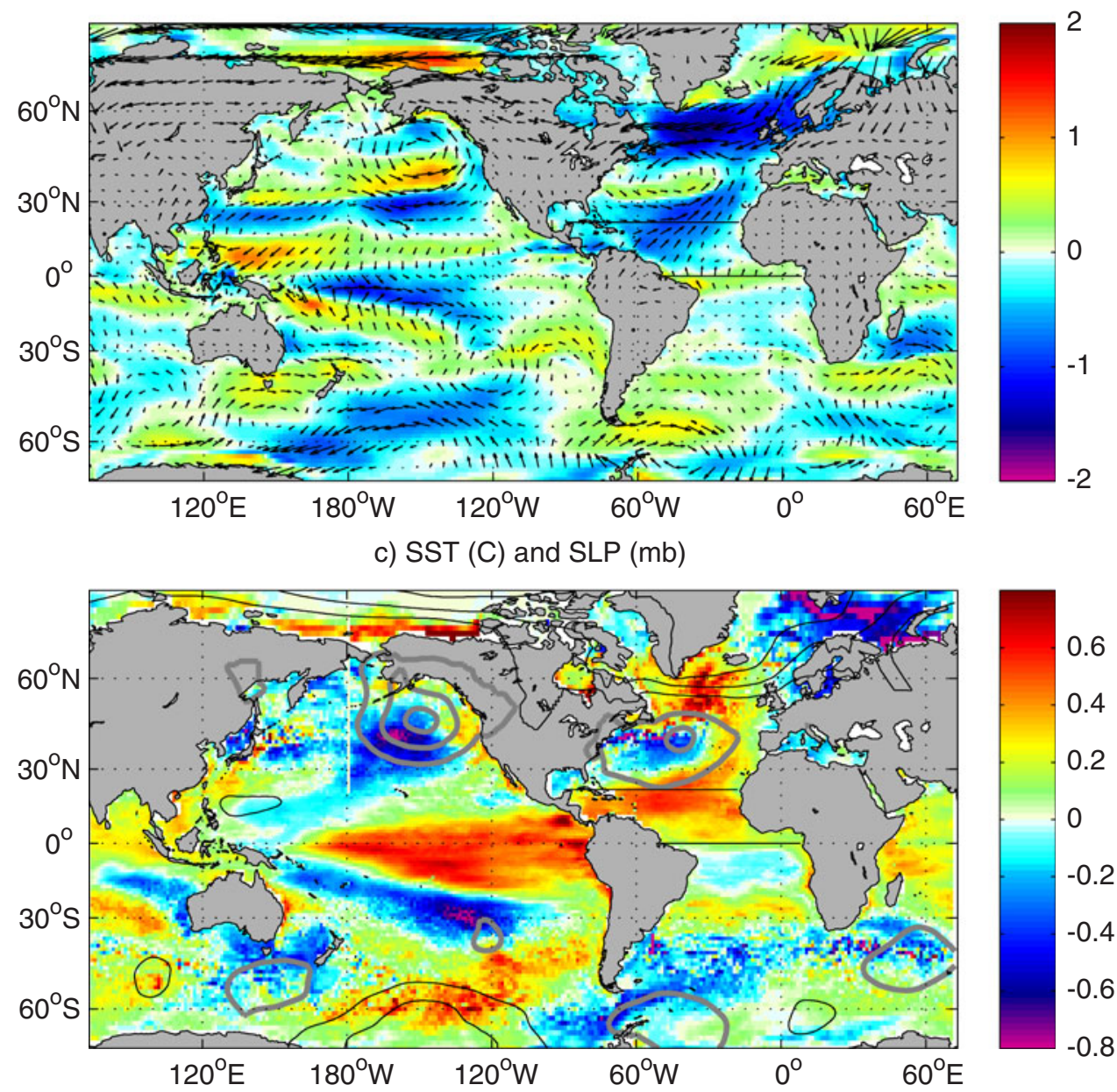

However, it should also be noted that the atmosphere plays a major role in driving variations in the surface heat exchange at mid-high latitudes, in particular through modes of variability including the North Atlantic Oscillation (NAO, e.g. Josey et al. 2001; Visbeck et al. 2003). A full evaluation of NAO-forced variability requires significant additional analysis which also includes consideration of the effects of other modes of atmospheric variability (e.g. the East Atlantic Pattern, Josey and Marsh 2005). We also note that in a recent coupled climate model analysis, we have 
Fig. 12 Hovmöller plots of different components of Atlantic Ocean meridional heat transport, 1958-2001. Total (a), MOC component (b) and gyre component (c). The black contours are the zonally averaged surface heat flux anomaly (contours of 4, 12 and $20 \mathrm{Wm}^{-2}$ in $\mathbf{a}, \mathbf{b}$ and $-4,-12$ and $-20 \mathrm{Wm}^{-2}$ in c). The solid grey line and the dashed grey lines indicate the climatological locations of the zero net heat flux and the $\pm 20 \mathrm{Wm}^{-2}$ net heat flux contours, respectively

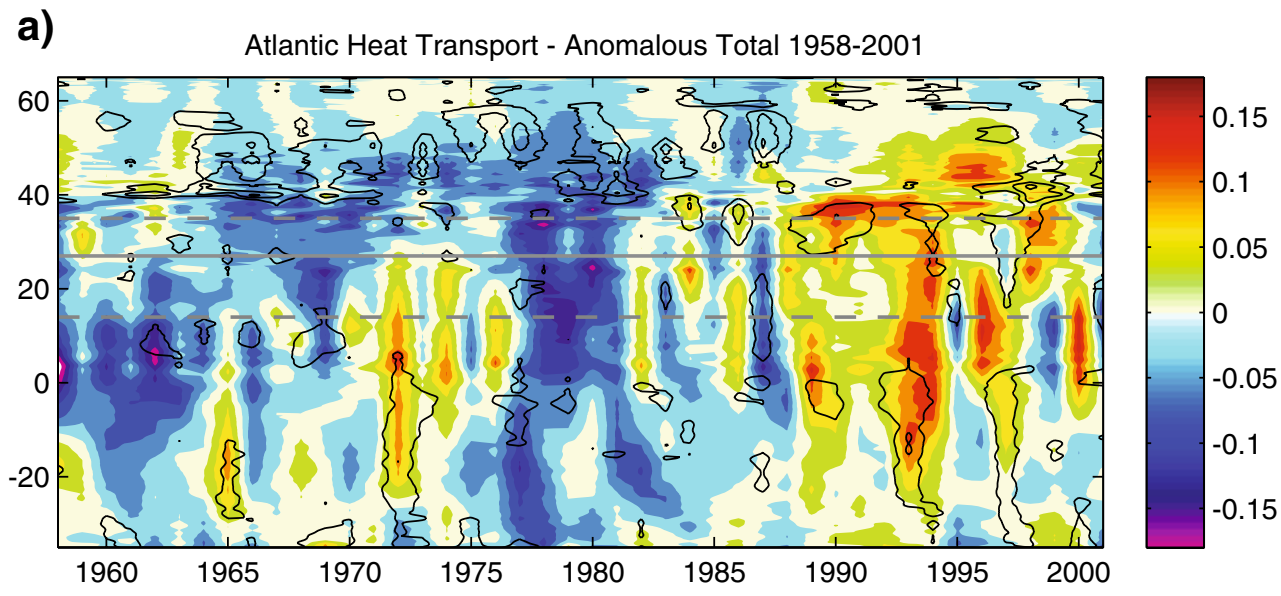

b)

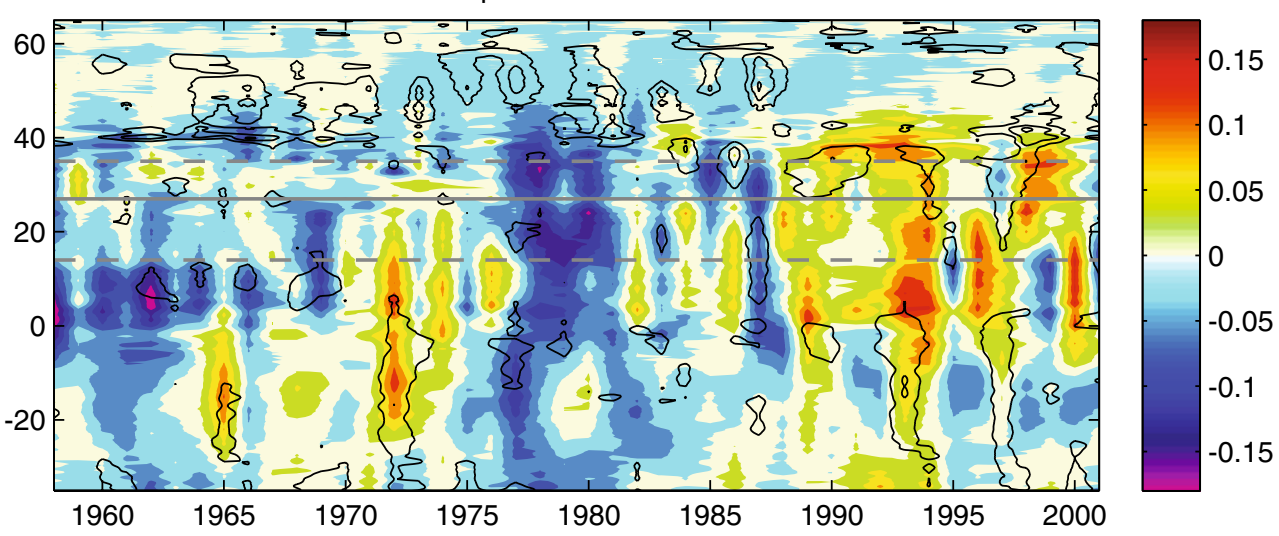

c)

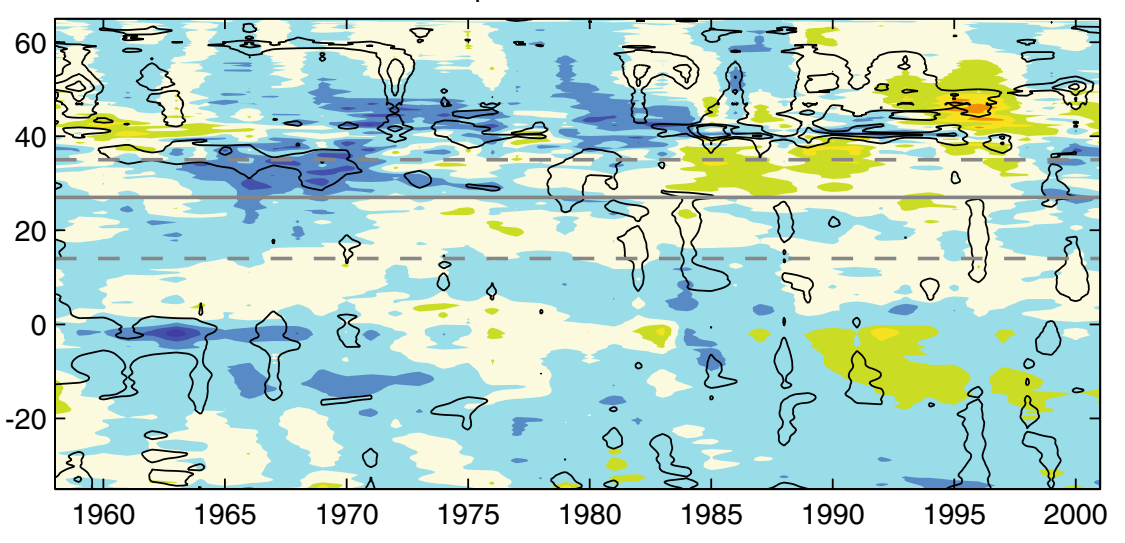

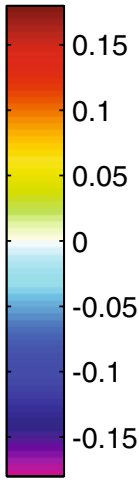

0.1 0.05 0.05 $-0.1$ $-0.15$ established a strong relationship between variations in the strength of the meridional overturning circulation and highlatitude surface heat and freshwater forcing within the framework of water mass transformation theory (Grist et al. 2009; Josey et al. 2009). Understanding the relationship between variations in the strength of the ocean heat transport and the MOC and linking them to the major atmospheric modes of variability is an area of ongoing research which we plan to address in subsequent work.

\section{Summary and conclusions}

The temperature and heat content variability of the Atlantic Ocean over the period 1958-2001 have been examined in this paper, with the main goal being to determine the relative contributions of surface heat fluxes and the convergence of ocean heat transport to historical changes in heat content. The focus of our study has been three regions of the North Atlantic: the North Atlantic subpolar 
gyre $\left(42-64^{\circ} \mathrm{N}\right)$, the North Atlantic Subtropical Gyre (22$\left.42^{\circ} \mathrm{N}\right)$ and the Tropical North Atlantic $\left(0-22^{\circ} \mathrm{N}\right)$, with the main tool being an integration of the ORCA025 eddypermitting model forced with historical surface meteorological observations. This approach is complementary to new observational techniques for separating the effects on heat content of changes in air-sea fluxes and ocean circulation, such as the depth and temperature contributions to "relative heat content" (Palmer and Haines 2009).

The magnitude and timing of the modelled temperature changes in the three study regions compared favourably with the recently compiled EN3v1c objectively analysed dataset. Our analysis further showed that with the exception of some small terms, such as eddy fluxes and diffusion, the model enables an accurate accounting of regional changes in heat content from the combined effect of OHT convergence and surface heat flux. The success of the ORCA025-N112 configuration in simulating and accounting for temperature variability in this region of densest historical observation suggests that the model can also be used for informative diagnostic studies in other parts of the Global Ocean.

The relative contribution of variability in OHT convergence and net surface heat flux to changes in ocean heat content varies both spatially and temporally:

- In the Subpolar Gyre region, we find a relatively stable positive heat content anomaly until the early 1970s. There is then a sharp decline, followed by values close to zero until the early 1980s and a further sudden drop resulting in a negative heat content anomaly which persists until the mid-1990s, before a return to nearnormal conditions in the early 2000s. The major influence on these changes has been sustained multiyear OHT convergence anomalies, with heat flux anomalies playing a relatively minor role.

- In contrast, the Subtropical Gyre region exhibits relatively little variability in ocean heat content over the past 50 years, and the small changes which have occurred are again primarily due to OHT convergence anomalies.

- The Tropical North Atlantic region experiences stronger changes over the model run with an initial cooling until the early 1960 s, followed by a prolonged warming to the early 1980s and substantial interannual variability, with heat transport convergence anomalies and surface heat flux anomalies contributing in roughly equal measure to the changes.

Comparison of the three regions suggests that the surface heat flux plays a relatively minor role in year-to-year changes in the Subpolar and Subtropical regions, but in the Tropical North Atlantic, its role is of similar significance to the OHT convergence. For the latter region, over the 44-year time series, in 7 out of 15 warming years and 7 out of 14 cooling years, anomalous surface heat flux was the greater contributor to ocean heat content change. Having established a greater role for surface fluxes in the Tropical North Atlantic, we investigated if there was a common cause influencing the surface fluxes in this region and have confirmed a link to El Niño. Further work is required to explore this relationship in more detail, but it appears that remote variability in the Pacific is partly responsible for meridional differences in the relative contributions of surface forcing and ocean heat transport to ocean heat content variability in the North Atlantic. Whilst the integral treatment of ocean heat content variability in three zones masks a substantial extent of regional structure, changes of heat content during the altimeter era (post-1993) are broadly consistent with the steric signal in sea surface height that is both observed by satellite and simulated with a similar configuration of the DRAKKAR model. Evaluated thus over 1993-2001, sea level has risen in the warming subpolar gyre whilst remaining steadier in the subtropical gyre (Lombard et al. 2009).

We have also explored whether the model OHT anomalies can be directly linked to surface flux anomalies through a Hovmöller analysis of the entire Atlantic sector. At low-mid latitudes $\left(30^{\circ} \mathrm{S}\right.$ to $\left.40^{\circ} \mathrm{N}\right)$, we find that increased ocean heat gain coincides with anomalously strong transport to higher latitudes. This is consistent with positive tropical heat flux warming the low-latitude ocean and increasing the northward ocean heat transport. By contrast, north of $40^{\circ} \mathrm{N}$, reduced ocean heat loss is typically found at the northern end of bands of weakened northward ocean heat transport. This is consistent with reduced poleward heat transport resulting in weaker heat loss to the atmosphere. Thus, the model analysis suggests that surface heat flux variability drives heat transport variability at low-mid latitudes and vice versa at higher latitudes.

It should be noted that the model run considered was carried out at $1 / 4^{\circ}$ and was thus eddy-permitting rather than eddy-resolving, a distinction that has been shown to influence both dynamical balances and current positions in the North Atlantic (Hecht and Smith 2008) and, specifically, the mechanisms governing heat transport variability (Marsh et al. 2009). A further run at $1 / 12^{\circ}$ is planned in the near future, and we plan to test the robustness of our results using this new eddy-resolving hindcast. In summary, we have found an encouraging level of agreement in historical variations of North Atlantic ocean heat content between the ORCA025 eddy-permitting model hindcast and the EN3v1c observational dataset over the period 1958-2001. Detailed analysis of the model fields has shown that changes in heat content in the North Atlantic and Subpolar and Subtropical Gyre regions are dominated by the variability in the OHT, whereas in the Tropical North Atlantic, the influence of surface flux and OHT are comparable. 
Acknowledgements This research has been supported by the UK Natural Environment Research Council Oceans 2025 programme. A number of the calculations were carried out using the CDFTOOLS program library produced by Jean-Marc Molines. Simon Good was supported by the Joint DECC and Defra Integrated Climate Programme, DECC/Defra (GA01101).

Open Access This article is distributed under the terms of the Creative Commons Attribution Noncommercial License which permits any noncommercial use, distribution, and reproduction in any medium, provided the original author(s) and source are credited.

\section{References}

Aagaard K, Greisman P (1975) Towards new mass and heat budgets for the Arctic Ocean. J Geophys Res 80:3821-3827

Bacon S (1997) Circulation and fluxes in the North Atlantic between Greenland and Ireland. J Phys Oceanogr 27:1420-1435

Barnier B, Madec G, Penduff T, Molines J-M, Treguier A-M, Le Sommer J, Beckmann A, Biastoch A, Böning C, Dengg J, Derval C, Durand E, Gulev S, Remy E, Talandier C, Theetten S, Maltrud M, McClean J, De Cuevas B (2006) Impact of partial steps and momentum advection schemes in a global ocean circulation model at eddy permitting resolution. Ocean Dyn 56:543-567. doi:10.1007/s10236-006-0082-1

Biastoch A, Böning C, Getzlaff J, Molines J-M, Madec G (2008a) Causes of interannual-decadal variability in the meridional overturning circulation of the mid-latitude North Atlantic Ocean. J Climate 21:6599-6615. doi:10.1175/2008JCLI2404.1

Biastoch A, Lutjeharms JRE, Böning CW, Scheinert M (2008b) Mesoscale perturbations control inter-ocean exchange south of Africa. Geophys Res Lett 35:L20602. doi:10.1029/2008GL035132

Böning CW, Scheinert M, Dengg J, Biastoch A, Funk A (2006) Decadal variability of subpolar gyre transport and its reverberation in the North Atlantic overturning. Geophys Res Lett 33: L21S01. doi:10.1029/2006GL026906

Brodeau L, Barnier B, Penduff T, Treguier A-M, Gulev S (2010) An ERA40 based atmospheric forcing for global ocean circulation models. Ocean Model 31:88-104. doi:10.1016/j.ocemod.2009.10.005

Bryden HL, Imawaki S (2001) Ocean heat transport. In: Siedler G, Church J, Gould J (eds) Ocean circulation and climate. Academic, San Diego, pp 455-474

Curry RG (1996) HydroBase: a database and tools for climatological analysis. Tech. Rep. WHOI-9601, Woods Hole Oceanographic Institution

Curry RG, McCartney MS, Joyce TM (1998) Oceanic transport of subpolar climate signals to mid-depth subtropical waters. Nature 391:575-577

Dai A, Trenberth KE (2002) Estimates of freshwater discharge from continents: latitudinal and seasonal variations. J Hydroeteorol 3:660-687

de Boyer MC, Madec G, Fischer AS, Lazar A, Iudicone D (2004) Mixed layer depth over the global ocean: an examination of profile data and a profile-based climatology. J Geophys Res 109: C12003. doi:10.1029/2004JC002378

DRAKKAR Group (2007) Eddy-permitting ocean circulation hindcasts of past decades. CLIVAR Exchanges No 4212 (3): $8-10$

Enfield DB, Mayer DA (1997) Tropical Atlantic sea surface temperature variability and its relation to El Niño-Southern Oscillation. J Geophys Res Oceans 102:929-945

Grist JP, Josey SA (2003) Inverse analysis of the SOC air-sea flux climatology using ocean heat transport constraints. J Climate 16:3274-3295
Grist JP, Marsh R, Josey SA (2009) On the relationship between the North Atlantic meridional overturning circulation and the surface-forced overturning stream function. J Climate 22:49895002. doi:10.1175/2009JCLI2574.1

Häkkinen S, Rhines PB (2004) Decline of subpolar North Atlantic circulation during the 1990s. Science 204:555-559

Häkkinen S, Rhines PB (2009) Shifting surface currents in the northern North Atlantic Ocean. J Geophys Res Oceans 114: C04005. doi: $10.1029 / 2008 J C 004883$

Hecht MW, Smith RD (2008) Towards a physical understanding of the North Atlantic: a review of model studies in an eddying regime. In: Hecht MW, Hasumi H (eds) Ocean modeling in an eddying regime. Geophysical monograph series, vol 177. American Geophysical Union, Washington, p 409

Holfort J, Siedler G (2001) The meridional oceanic transports of heat and nutrients in the South Atlantic. J Phys Oceanogr 31:5-29

Horel JD, Wallace JM (1981) Planetary scale atmospheric phenomena associated with the Southern Oscillation. Mon Wea Rev 109:813-829

Ingleby B, Huddleston M (2007) Quality control of ocean temperature and salinity profiles - historical and real-time data. J Mar Sys 65:158-175. doi:10.1016/j.jmarsys.2005.11.019

Josey SA, Marsh R (2005) Surface freshwater flux variability and recent freshening of the North Atlantic in the eastern subpolar gyre. J Geophys Res 110:C05008. doi:10.1029/2004JC002521

Josey SA, Kent EC, Sinha B (2001) Can a state of the art atmospheric general circulation model reproduce recent NAO related variability at the air-sea interface? Geophys Res Lett 28:4543-4546

Josey SA, Grist JP, Marsh R (2009) Estimates of meridional overturning circulation variability in the North Atlantic from surface density flux fields. J Geophys Res 114:C09022. doi:10.1029/2008JC005230

Jourdan D, Balopouls E, Garcia-Fernandez MJ, Maillard C (1998) Objective analysis of temperature and salinity historical data set over the Mediterranean Basin. IEEE Press, Piscataway

Klein B, Molinari RL, Mueller TJ, Siedler G (1995) A transatlantic section at $14.5^{\circ} \mathrm{N}$ : meridional volume and heat fluxes. J Mar Res 53:929-957

Klotzbach PJ (2007) Recent developments in statistical prediction of seasonal Atlantic basin tropical cyclone activity. Tellus 59A:511518. doi:10.1111/j.1600-0870.2007.00239.x

Large WG, Yeager SG (2004) Diurnal to decadal global forcing for ocean and sea-ice models: the data sets and flux climatologies. Technical Report TN-460+STR, NCAR, 105 pp

Lavin A, Bryden HL, Parrilla G (1998) Meridional transport and heat flux variations in the subtropical North Atlantic. Global Atmos Ocean Syst 6:269-293

Leadbetter SJ, Williams RG, McDonagh EL, King BA (2007) A twenty year reversal in water mass trends in the subtropical North Atlantic. Geophys Res Lett 34:L12608. doi:10.1029/2007/ GL029957

Levitus S, Boyer TP, Conkright ME, O'Brian T, Antonov J, Stephens C, Stathopolos L, Johnson D, Gelfeld R (1998) World Ocean Database 1998. NOAA Atlas NESDID 18. US Government Printing Office, Washington

Levitus S, Antonov JI, Boyer TP, Locarnin RA, Garcia HE, Mishonov AV (2009) Global ocean heat content 1955-2008 in light of recently revealed instrumentation problems. Geophys Res Lett 36:L07608. doi:10.1029/2008GL03715

Lombard A, Garric G, Penduff T (2009) Regional patterns of observed sea level change: insights from a $1 / 4^{\circ}$ global ocean/sea ice hindcast. Ocean Dyn 59:433-449. doi:10.1007/s10236-008-0161-6

Lozier MS, Leadbetter S, Williams RG, Roussenov V, Reed MSC, Moore NJ (2008) The spatial pattern and mechanism of heatcontent change in the North Atlantic. Science 319:800-803. doi:10.1126/science. 1146436 
Madec G (2008) NEMO reference manual, ocean dynamic component: NEMO-OPA. Preliminary version, Tech. Rep. 27, Note du pôle de modélisation, Institut Pierre Simmon Laplace (IPSL), France. ISSN No. 1288-1619

Madec G, Delecluse P, Imbard M, Levy C (1998) OPA 8.1 ocean general circulation model reference manual. IPSL Tech. Rep. Tech Rep. 11, Institut Pierre-Simon Laplace, $91 \mathrm{pp}$

Marsh R, Josey SA, de Cuevas BA, Redbourn LJ, Quartly GD (2008) Mechanisms for recent warming of the North Atlantic: insights gained with an eddy-permitting model. J Geophys Res 113: C04031. doi:10.1029/2007JC004096

Marsh R, de Cuevas BA, Coward AC, Jaquin J, Hirschi JJ-M, Aksenov Y, Nurser AJG, Josey SA (2009) Recent changes in the North Atlantic circulation simulated with eddy-permitting and eddy resolving ocean models. Ocean Model 28:226-239. doi:10.1016/j.ocemod.2009.02.007

Niebauer HJ (1988) Effects of El Nino-Southern Oscillation and North Pacific weather patterns on interannual variability in the subarctic Bering Sea. J Geophys Res 93(C):5051-5068

Palmer MD, Haines K (2009) Estimating oceanic heat content change using isotherms. J Climate 22:4953-4969

Penduff T, Le Sommer J, Barnier B, Treguier AM, Molines JM, Madec G (2007) Influence of numerical schemes on currenttopography interactions in $1 / 4^{\circ}$ global ocean simulations. Ocean Sci 3:509-524. www.ocean-sci.net/3/509/2007/

Penduff, T, Juza M, Brodeau L, Smith GC, Barnier B, Molines J-M, Treguier A-M, Madec G (2010) Impact of global ocean model resolution on sea-level variability with emphasis on interannual timescales. Ocean Sci 6:269-284. www.ocean-sci.net/6/269/ 2010
Philippon N, Fontaine B (2000) West African June to September rainfall: experimental statistical forecasts based on April values of regional predictors. Experimental Long-lead Forecast Bulletin 9

Scaife AA, Knight JR (2008) Ensemble simulations of the cold European winter of 2005-2006. Q J Royal Meteor Soc 134:1647-1659

Speer KG, Holfort J, Reynaud T, Siedler G (1996) South Atlantic heat Transport at $11^{\circ} \mathrm{S}$. The South Atlantic: present and past circulation. Springer, Berlin

Steele M, Morley R, Ermold W (2001) PHC: a global ocean hydrography with a high quality Artic Ocean. J Climate 14:2079-2087

Thierry V, de Boisseson E, Mercier H (2008) Interannual variability of the subpolar mode water properties over the Reykjanes Ridge during 1990-2006. J Geophys Res 113:C04016. doi:10.1029/ 2007JC004443

Timmerman R, Goosse H, Madec G, Fichefet T, Ethe C, Dulière V (2005) On the representation of high latitude processes in the ORCA-LIM global coupled sea-ice ocea model. Ocean Model 8:175-201. doi:10.1016/j.ocemod.2003.12.009

Tompkins AM, Feudale L (2010) Seasonal ensemble predictions of West African monsoon precipitation in the ECMWF System 3 with a focus on the AMMA special observing period in 2006. Weather and Forecasting (in press). doi:10.1175/2009WAF2222236.1

Trenberth KE, Caron JM (2001) Estimates of meridional atmoshpere and ocean heat transports. J Climate 14:3433-3443

Visbeck M, Chassignet E, Curry R, Delworth T, Dickson R, Krahmann G (2003) The ocean's response to North Atlantic Oscillation variability. In: Hurrell JW, Kushnir Y, Ottersen G, Visbeck M (eds) The North Atlantic Oscillation. Geophysical Monograph Series, vol 134, pp 113-146 